\title{
Probabilistic tsunami hazard analysis for Tuzla test site using Monte Carlo simulations
}

\author{
Hafize Basak Bayraktar ${ }^{1,2}$ and Ceren Ozer Sozdinler ${ }^{3}$ \\ ${ }^{1}$ Department of Physics “Ettore Pancini”, University of Naples Federico II, Naples, 80126, Italy \\ ${ }^{2}$ Istituto Nazionale di Geofisica e Vulcanologia, Rome, Italy \\ ${ }^{3}$ Institute of Education, Research and Regional Cooperation for Crisis Management Shikoku, \\ Kagawa University, Takamatsu, 760-8521, Japan
}

Correspondence: Hafize Basak Bayraktar (hafizebasak.bayraktar@unina.it)

Received: 24 July 2019 - Discussion started: 5 September 2019

Revised: 10 January 2020 - Accepted: 9 February 2020 - Published: 15 June 2020

\begin{abstract}
In this study, time-dependent probabilistic tsunami hazard analysis (PTHA) is performed for Tuzla, Istanbul, in the Sea of Marmara, Turkey, using various earthquake scenarios of Prince Island Fault (PIF) within the next 50 and 100 years. The Monte Carlo (MC) simulation technique is used to generate a synthetic earthquake catalogue, which includes earthquakes having moment magnitudes between $M_{\mathrm{w}} 6.5$ and 7.1. This interval defines the minimum and maximum magnitudes for the fault in the case of an entire fault rupture, which depends on the characteristic fault model. Based on this catalogue, probability of occurrence and associated tsunami wave heights are calculated for each event. The study associates the probabilistic approach with tsunami numerical modeling. The tsunami numerical code NAMI DANCE was used for tsunami simulations. According to the results of the analysis, distribution of probability of occurrence corresponding to tsunami hydrodynamic parameters is represented. Maximum positive and negative wave amplitudes show that tsunami wave heights up to $1 \mathrm{~m}$ have $65 \%$ probability of exceedance for the next 50 years and this value increases by $85 \%$ in the Tuzla region for the next 100 years. Inundation depth also exceeds $1 \mathrm{~m}$ in the region with probabilities of occurrence of $60 \%$ and $80 \%$ for the next 50 and 100 years, respectively. Moreover, probabilistic inundation maps are generated to investigate inundated zones and the amount of water penetrated inland. Probability of exceedance of $0.3 \mathrm{~m}$ wave height ranges between $10 \%$ and $75 \%$ according to these probabilistic inundation maps, and the maximum inundation distance calculated in the entire earthquake catalogue is $60 \mathrm{~m}$ in this test site. Furthermore, synthetic gauge
\end{abstract}

points are selected along the western coast of Istanbul by including Tuzla coasts. Tuzla is one of the areas that shows high probability exceedance of $0.3 \mathrm{~m}$ wave height, which is around $90 \%$, for the next 50 years while this probability reaches up to more than $95 \%$ for the next 100 years.

\section{Introduction}

The Marmara region, especially highly populated cities along the coasts of the Marmara Sea, is the heart of the Turkish economy in terms of having a great number of industrial facilities with the largest capacity and potential, refineries, ports and harbors. The Marmara Sea and surrounding area is one of the most seismically active areas in Turkey. Main active faults of the region pass through the Marmara Sea. Thus, coastal cities in the Marmara region, especially Istanbul, which has significant importance in terms of the economy and historical and sociocultural heritage with a population of more than 15 million, are under the threat of high damage due to possible big earthquakes and also triggered tsunamis. Recent studies and evaluation of earthquake recurrence periods revealed that there is a high possibility of having an earthquake with a magnitude larger than $M_{\mathrm{w}} 7.0$ in the Prince Island Fault (PIF). According to Ambraseys (2002), the last earthquake on this fault system occurred in 1766 and since that time this fault has been accumulating a huge amount of energy. According to Parsons (2004), the probability of occurrence of a $M>7$ earthquake beneath the Marmara Sea was estimated to be $35 \%-70 \%$ in the following 
30 years. The region has distinctive characteristics in terms of its complex tectonic structure and the high possibility of an earthquake occurrence with a magnitude larger than 7.0 offshore of Istanbul. Therefore, there has been a wide range of studies in the Marmara Sea region regarding the fault mechanisms, seismic activities, earthquakes, and triggered tsunamis (Armijo et al., 2002, 2005; Okay et al., 1999; Le Pichon et al., 2001; Yaltırak, 2002; McNeill et al., 2004; Aksu et al., 2000; Imren et al., 2001; Pondard et al., 2007; Yalçıner et al., 1999, 2000, 2002; Aytore et al., 2016; Hébert et al., 2005; Altınok et al., 2003, 2011; Guler et al., 2015; Cankaya et al., 2016; Tufekci et al., 2018; Latcharote et al., 2016).

The North Anatolian Fault Zone (NAFZ) controls a great part of the seismic activity in the Marmara Sea region. The fault zone sets apart Anatolia (Asian part of Turkey) and Eurasia due to the northward migration of the Arabian Plate in the east and southward rollback of the Hellenic subduction zone in the west as seen in Fig. 1 (Armijo et al., 1999; Flerit et al., 2004; Le Pichon et al., 2015).

The Marmara Sea region is a transition zone between the strike-slip regime of the NAFZ and the extension regime of the Aegean Sea area (top left of Fig 1). The northern branch of the NAFZ forms a major transtensional NW-SE right bend under the Sea of Marmara at the Çınarcık trough (Murru et al., 2016). The fault trace is attached to the complex Central Marmara and Tekirdağ pull-apart basins, before joining the NE-SW-striking Ganos fault on land by following the northern margin of the Marmara Sea. Finally, the fault exits into the Aegean Sea by way of Saros Gulf (Wong et al., 1995; Armijo et al., 1999, 2002; Okay et al., 1999; Le Pichon et al., 2001; Yaltırak, 2002; McNeill et al., 2004). The fault trace beneath the Marmara Sea is not directly observable. Therefore, making a segmentation model for the offshore parts of the NAFZ is quite challenging, which causes the fault dimensions, such as its length and width, to include a sum of error margin (Aksu et al., 2000; Imren et al., 2001; Le Pichon et al., 2001; Armijo et al., 2002, 2005; Pondard et al., 2007).

The current right-lateral slip rate along the NAFZ is about $25 \mathrm{~mm} \mathrm{yr}^{-1}$ (Meade et al., 2002; Reilinger et al., 2006). On the western side, the motion between the Anatolian and Eurasian plates is accommodated across the Marmara region by $\sim 19 \mathrm{~mm} \mathrm{yr}^{-1}$ of right-lateral slip and $8 \mathrm{~mm} \mathrm{yr}^{-1}$ of extension (Flerit et al., 2003, 2004). Slip rates of the main Marmara fault range between 17 and $28 \mathrm{~mm} \mathrm{yr}^{-1}$ (Le Pichon et al., 2003; Reilinger et al., 2006). On the other hand, Hergert and Heidbach (2010) suggest that the right-lateral slip rate on the main Marmara fault is between 12.8 and $17.8 \mathrm{~mm} \mathrm{yr}^{-1}$ due to slip partitioning and internal deformation. The right-lateral slip rate for the PIF and Çınarcık basin is $15 \pm 2 \mathrm{~mm} \mathrm{yr}^{-1}$ and in addition to this the fault has $6 \pm 2 \mathrm{~mm} \mathrm{yr}^{-1}$ of extension (Ergintav et al., 2014).

The main characteristic of the NAFZ is that the earthquakes systematically propagate westward, and historical records show that the northern strand of the NAFZ generates earthquakes with the recurrence interval of about 250 years beneath the Marmara Sea; the last event occurred in 1766 (Ambraseys, 2002; Bohnhoff et al., 2013). This event caused the rupture of the $58 \mathrm{~km}$ long northern part of the NAFZ from İzmit to Tekirdağ (Ambraseys and Finkel, 1995; Ambraseys and Jackson, 2000). However, the earthquake that happened on 2 September 1754 can be considered the last characteristic event for the PIF segment, and it caused the rupture of a $36 \mathrm{~km}$ long fault segment (Ambraseys and Jackson, 2000). The NAFZ has experienced two $M>7$ earthquakes: in August 1912 in Ganos and August 1999 at İzmit. After the 1999 İzmit event, seismic energy along the $150 \mathrm{~km}$ long northern part of the NAFZ has been accumulating continuously since the 22 May 1766 earthquake. This fault zone extends right to the south of Istanbul beneath the Marmara Sea, and this situation increases the rupture possibility of the PIF and the risk for Istanbul (Stein et al., 1997; Barka, 1999; Bohnhoff et al., 2013). Ergintav et al. (2014) also indicated that the PIF segment accumulates stress $15 \pm 2 \mathrm{~mm} \mathrm{yr}^{-1}$, and the $3.7 \mathrm{~m}$ slip deficit has been accumulating since the 1766 events. This makes the PIF most likely to generate the next $M>7$ earthquake along the Sea of Marmara segment of the NAF.

Besides these seismic activities in the region, studies of the historical tsunami records show that 35 tsunami events happened between 330 BCE and 1999 BCE in the Marmara Sea region, and the majority of them are earthquakerelated tsunami events (Altinok et al., 2011; Yalçıner et al., 2002). The 1509 earthquake, with an estimated magnitude around 7.5 (Ambraseys, 2002), is one of the examples for these events. This earthquake triggered a tsunami and the tsunami waves inundated the Istanbul coast, reaching the city walls and killing around 4000-5000 people in the city (Ambraseys and Finkel, 1995). The 1894 earthquake is also one of the important events that happened in the Marmara Sea. The earthquake triggered a tsunami and the sea inundated $200 \mathrm{~m}$ of coast in Istanbul (Altinok et al., 2011). The most recent event happened after the 17 August 1999 İzmit earthquake, and after the earthquake E-W-trending tectonic deformation along the basin and submarine failures generated a tsunami. The International Tsunami Survey Team (Yalciner et al., 1999, 2000) investigated the region and they observed $2.66 \mathrm{~m}$ run-up along the coast from Tütünçiftlik to Hereke and $2.9 \mathrm{~m}$ run-up at Değirmendere (Yalçıner et al., 2002).

Several tsunami hazard estimation studies (Ozer Sozdinler et al., 2020; Hancilar, 2012; Aytore et al., 2016; Hébert et al., 2005) were also conducted in the region. These tsunami analyses were mostly performed in a deterministic manner using various earthquake scenarios depending on the combinations of different fault parameters without considering probability of occurrences. The $40 \mathrm{~km}$ long fault in the eastern basin of the Marmara Sea, with a significant normal component, may generate tsunami waves which can reach maximum $2 \mathrm{~m}$ heights along the Istanbul coast with considerable local inundation (Hébert et al., 2005). The rupture of the Yalova Fault, 


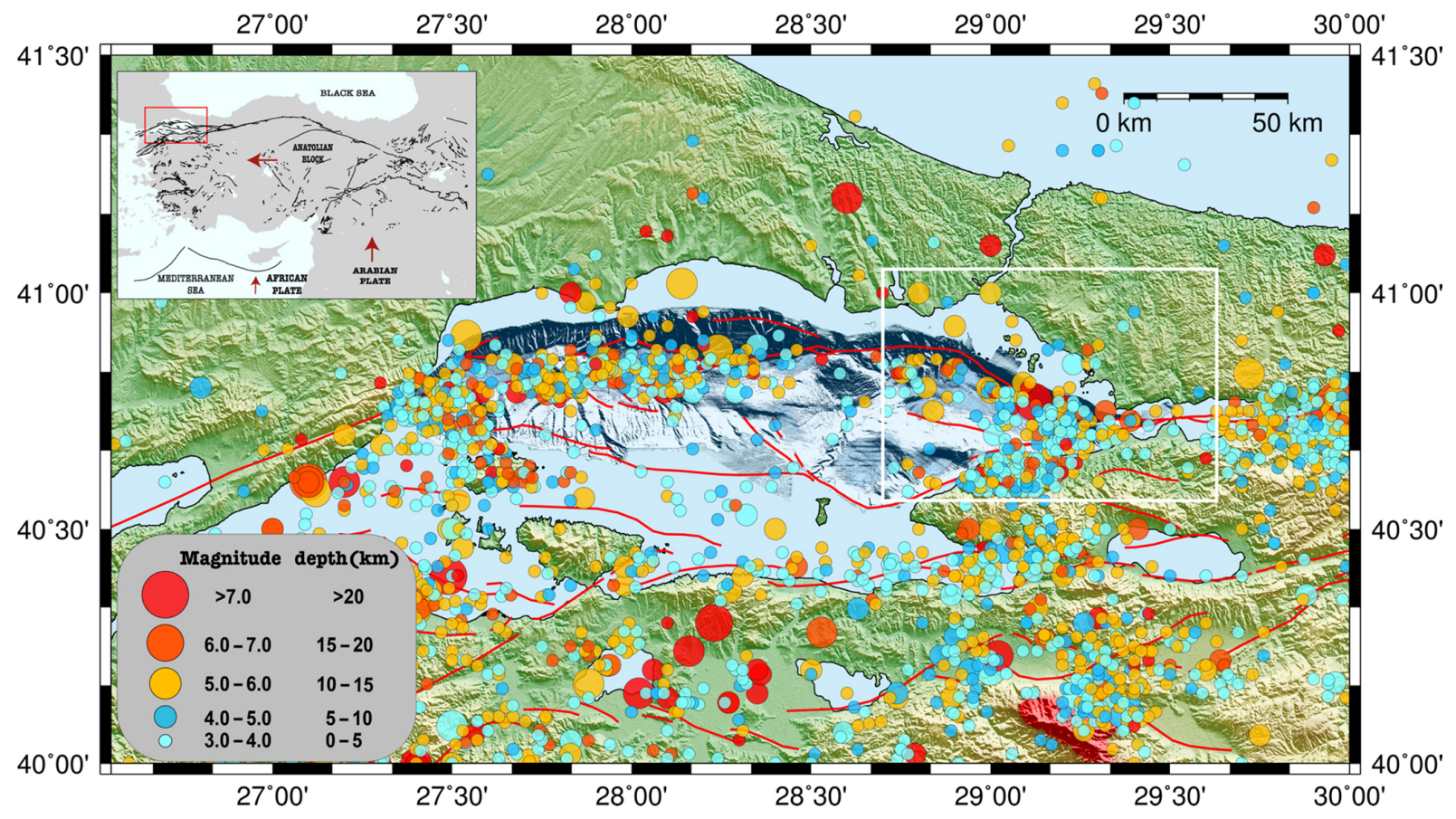

Figure 1. Seismicity map of the Marmara region and general tectonic map of Turkey at the top left. In the seismicity map, the size of the circles changes with magnitude of the earthquakes, and the color of the circles defines the depth change of the earthquakes. Red lines show the known active faults (modified from Emre et al., 2013) in the region, and the white square is the area with the PIF. In the general tectonic map of Turkey, red arrows show the direction of the plate motion, black lines show the active faults in the region (modified from Emre et al., 2013), and the red rectangle shows the Marmara region (created using The Generic Mapping Tools, version 5.4.1). The duration of the catalog, used for the seismicity map, is 05 April 1905-31 December 2018 (KOERI, 2001).

PIF, or Central Marmara Fault can also cause serious damage along the coast of Istanbul. Tsunami wave heights can reach $4.8 \mathrm{~m}$ and can penetrate $340 \mathrm{~m}$ inwards from the coast in Haydarpaşa Port (Aytore et al., 2016).

A few probabilistic seismic and tsunami hazard analyses (Murru et al., 2016; Erdik et al., 2004; Hancilar, 2012) were also performed in this region. Seismic hazard maps were prepared in the Marmara Sea region by describing fault segments and peak ground accelerations with the periods corresponding to $10 \%$ and $2 \%$ probabilities of exceedance in 50 years (Erdik et al., 2004). In addition, tsunami inundation maps are prepared based on probabilistic and deterministic analyses by depending on these segmentations (Hancilar, 2012). Time-dependent and time-independent earthquake ruptures are also estimated in the Marmara Sea region for the next 30 years (Murru et al., 2016). These previous studies have been conducted for entire Marmara Sea region and therefore they give general and rough information about probability of occurrence in the region without focusing on any specific region in high resolution. However, probabilistic tsunami hazard assessment is important to calculate the tsunami exposure and risk on human populations and infrastructures, since probability calculations consider all possible earthquakes in a fault even if they occur with very low probability (Løvholt et al., 2012, 2015; Grezio et al., 2017). The results of probabilistic studies should be considered when decision makers design coastal zones and structures, especially critical ones. Different from previous probabilistic approaches in the Marmara Sea, the probability of earthquake occurrences in one fault segment, PIF, are taken into account for the preparation of high-resolution tsunami inundation maps and distribution of hydrodynamic parameters due to the probability of occurrence of associated earthquakes on the PIF determined by Monte Carlo (MC) simulations.

This probabilistic tsunami hazard analysis (PTHA) study depends on the fully characteristic fault model, and the main purpose is to perform PTHA for selected test sites. The Tuzla test site is one of the coastal districts of Istanbul and located on the southernmost part of the city (Fig. 2). The region includes several residential areas, but the most critical point about the region is that Tuzla has the biggest shipyard area not only in the Marmara Sea but also in Turkey (Fig. 3). In this study we mainly focused on this region because it is about $20 \mathrm{~km}$ away from the PIF and therefore has a high risk of both earthquake and tsunami damage.

\section{Probabilistic analysis}

Probabilistic tsunami hazard analysis (PTHA), as it is recently becoming a widely used procedure for coastal zones, 

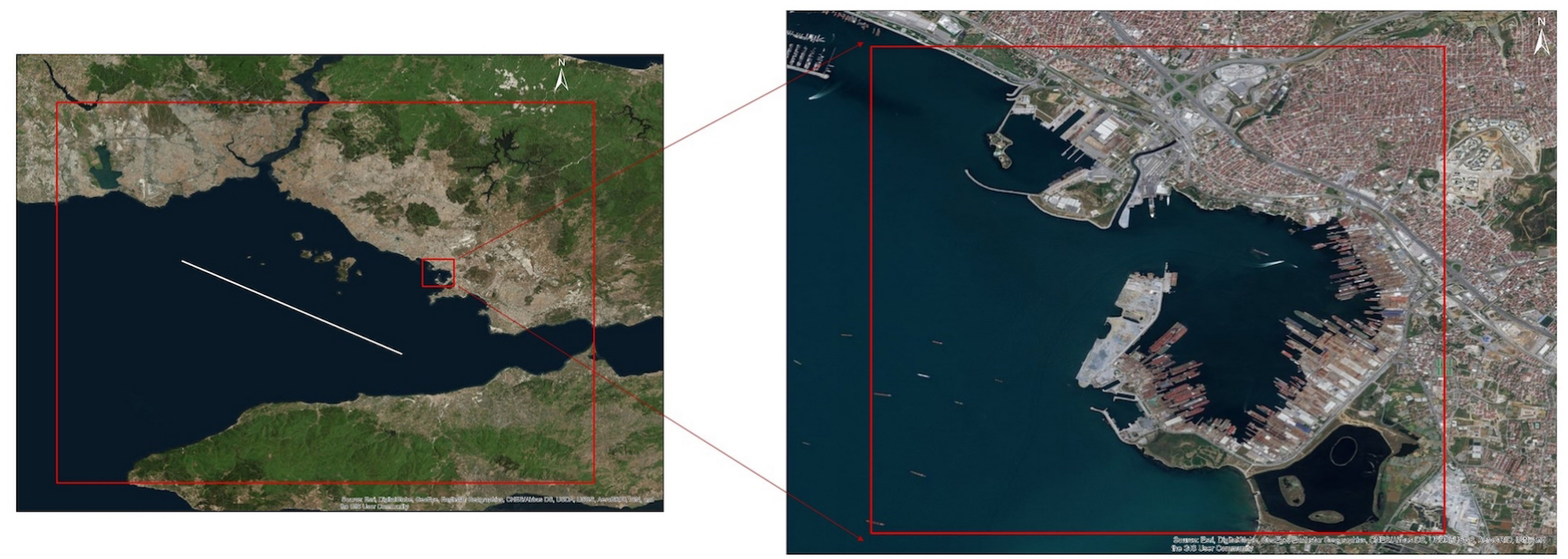

Figure 2. The Marmara Sea region, Tuzla test site, and the location of the PIF segment which is used in the analysis like a straight line (created using ArcMap version 10.5).

is performed for the Tuzla region, Istanbul. This method has been applied for various tsunami sources, such as earthquakes, landslides, volcanic activities, etc., on various scales, local, regional, and global (Grezio et al., 2017). For earthquake-generated tsunamis, the method is generally adapted from seismic hazard assessment methods (González et al., 2009). Such kinds of studies consider the events that are generated by coseismic seafloor displacement, using seismic probabilistic hazard analysis (SPTHA), but numerous tsunami simulations are required to consider all expected combinations of seismic sources. This problem can be solved by applying a simplified event tree approach and a twostage filtering procedure to reduce the number of required source scenarios without decreasing the quality and accuracy of inundation maps (Lorito et al., 2015). The earthquake source itself is very uncertain and the investigation of this uncertainty can be carried out by building an event tree instead of using a logic tree and hazard integrals (Selva et al., 2016). The logic tree approach can be applied to the generation of tsunami hazard curves to decrease the uncertainties by including branches, which are the combination of tsunami sources, magnitude distribution of characteristic tsunamigenic earthquakes, their recurrence interval, and the tsunami height estimation procedure based on a numerical simulation (Annaka et al., 2007). For regional studies, hazard curves can be generated by empirical analysis using available tsunami run-up data. However, if such data are not available, MC simulations, a computationally based method widely used in probabilistic seismic hazard analysis (PSHA), can be considered as a primary method to generate tsunami hazard curves (Geist and Parsons, 2006; Horspool et al., 2014). Submarine landslides, on the other hand, are the major tsunami source for passive margins, which are the transition zone between the oceanic and continental lithosphere that is not an active plate boundary, and they have been included in
PTHA methodologies (Geist and Lynett, 2014). Probabilistic studies are also applied to develop multi-hazard loss estimation methodology for coastal regions that are exposed to cascading shaking-tsunami hazards due to offshore mega-thrust subduction earthquakes (Goda and De Risi, 2018).

In this study, a characteristic earthquake model is used to estimate the earthquake recurrence on the PIF. Paleoseismologic studies (Ryall et al., 1966; Allen, 1968; Schwartz and Coppersmith, 1984) suggest that an individual fault tends to generate characteristic earthquakes having a very narrow range of magnitudes. These individual faults have a different frequency distribution than the log linear Gutenberg-Richter frequency-magnitude relationship (Aki, 1984; Schwartz and Coppersmith, 1984; Youngs and Coppersmith, 1985). According to Aki (1984), a characteristic earthquake is generated as a result of constancy of barriers to rupture through repeated seismic cycles.

PIF is fully characteristic and a characteristic earthquake will rupture an entire fault as a whole and release all the energy. Therefore, while performing MC simulations, the area of the fault and fault parameters (strike, dip, and rake angles) are used as constants referring to the outcomes of EU Seventh Framework Programme project MARSITE (Ozer Sozdinler et al., 2020). One of the work packages of this project aimed to define the geometry of the possible tsunamigenic faults in the Marmara Sea and 30 different earthquake scenarios with the different rupture combinations of 32 possible fault segments. Based on these 30 different earthquake scenarios, tsunami numerical modeling is performed. The definition of fault segments depends on extensive review of the literature (Alpar and Yaltırak, 2002; Altınok and Alpar, 2006; Armijo et al., 2005; Ergintav et al., 2014; Gasperini et al., 2011; Hébert et al., 2005; Hergert et al., 2011; Hergert and Heidbach, 2010; Imren et al., 2001; Kaneko, 2009; Le Pichon et al., 2001, 2003, 2014; Oglesby 


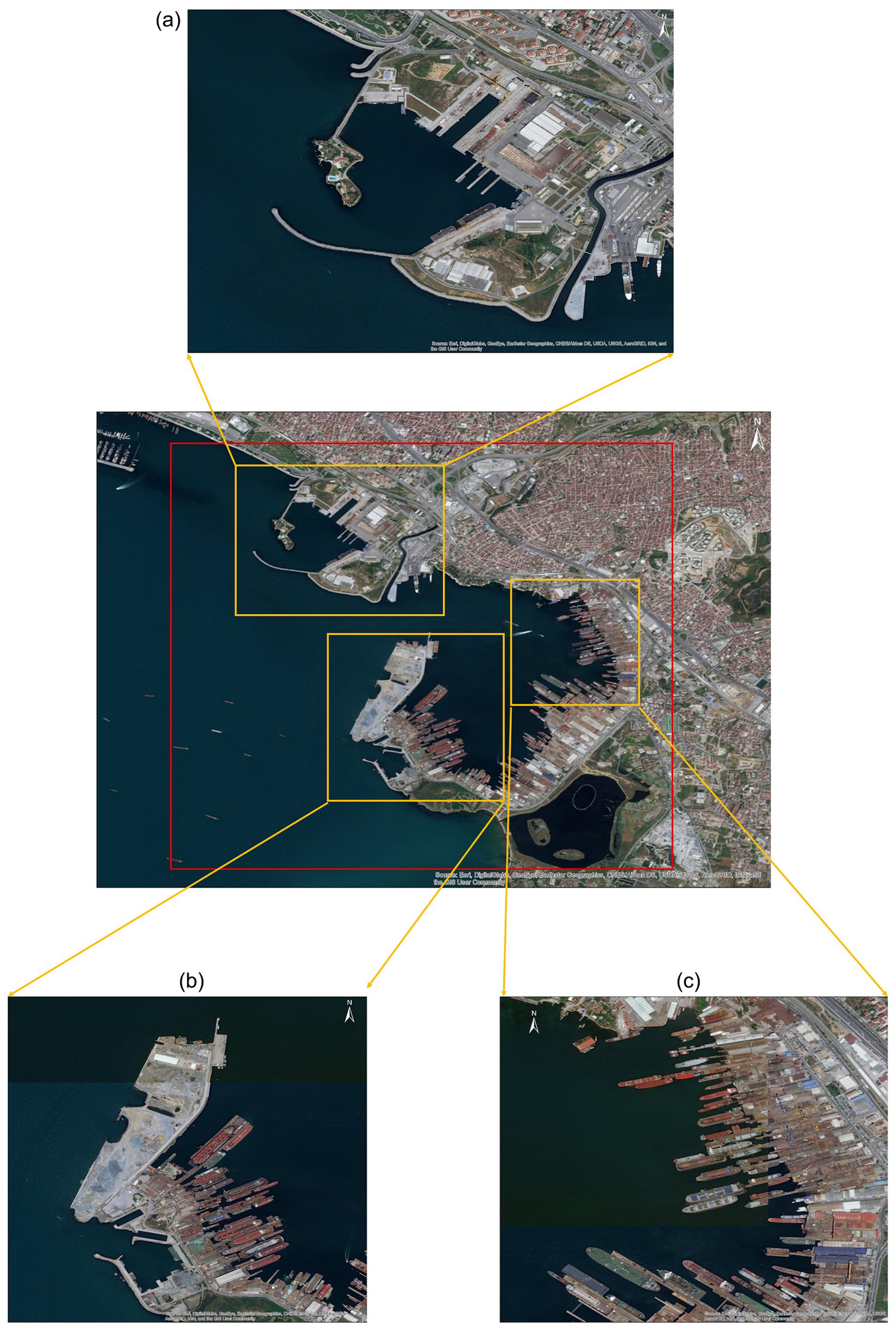

Figure 3. Some important locations at the Tuzla domain. (a) Northern part of the Tuzla domain. (b) Southern part of the Tuzla domain. (c) Tuzla shipyard (created using ArcMap version 10.5). 
Table 1. The area and the focal mechanism of the PIF zone. These are the constant parameters during the MC simulation application.

\begin{tabular}{lcccc}
\hline $\begin{array}{l}\text { Fault } \\
\text { length } \\
(\mathrm{km})\end{array}$ & $\begin{array}{l}\text { Fault } \\
\text { width } \\
(\mathrm{km})\end{array}$ & Strike & Dip & Rake \\
\hline 33.5 & 14 & 119 & 80 & 210 \\
\hline
\end{tabular}

and Mai, 2012; Şengör et al., 2014; Tinti et al., 2006; Utkucu et al., 2009). As a result of this review, each fault segment is defined as a rectangular area with hypothetical uniform slip. According to the results of the project, the fault parameters of the PIF are given in Table 1. The 3-D fault configuration given by Armijo et al. (2002), which explains fault segmentation in the region depending on morphology, geology, and long-term displacement fields, also fits with the PIF parameters that are used in the project. These parameters are used as constants in this study while assessing probability of occurrence of each earthquake to allow full fault rupture at different depths with different magnitudes.

The MC simulation technique is generally applied to generate an earthquake catalogue of a given length of time. In this technique, a list of earthquakes can be generated using the frequency-magnitude relationship for each seismic source (Zolfaghari, 2015). Seismic zonation should be performed by considering regions that have relatively homogeneous earthquake activity and faulting regimes (Sørensen et al., 2012). In this study, the fault segment model proposed in Ozer Sozdinler et al. (2020) is used and PIF is the only segment that is a seismic source. After that, tsunami numerical modeling is performed for each event of this synthetic catalogue, and tsunami hydrodynamic parameters, mainly maximum wave heights, inundation depth, current velocities, and tsunami inundation zones, are estimated. Tsunami risk assessment will serve the needs of societies best when regional studies are associated with the local ones (Sørensen et al., 2012).

The MC simulation technique allows the generation of a list of earthquakes based on a frequency-magnitude relationship. This technique depends on a uniformly distributed source model and it provides an equal likelihood to each earthquake source. As a result, the synthetic earthquake catalogue will have uniformly randomly distributed earthquake sources (Zolfaghari, 2015).

Using MC simulation, a synthetic earthquake catalogue is generated by selecting earthquake magnitude and depth as uniformly distributed random numbers in a given interval and using area and directivity of the fault as a constant variable (Table 1). We performed MC simulations 100 times for 100 different earthquake scenarios. The number of earthquakes in the catalog is selected as a reasonable number that represents the number of iterations randomly performed in MC simulations for having a synthetic earthquake sce- nario. As mentioned earlier, NAFZ generates an earthquake with the recurrence interval of about 250 years beneath the Marmara Sea. Therefore, selecting 100 earthquake scenarios would cover a time period of $100 \times 250 \mathrm{yr}=25000 \mathrm{yr}$, which is considered as an adequate catalog duration in this study. However, because of having time-dependent probabilistic analyses, this catalog duration is not used for PTHA in this study.

Earthquake magnitude is one of the parameters randomly selected by the MC technique. Based on a characteristic earthquake model, individual faults tend to rupture the entire fault when a large earthquake occurs. This model assumes that a characteristic earthquake releases all of the seismic energy during the fault rupture, and the magnitude of the earthquake depends on the dimension of the fault (Abrahamson and Bommer, 2005).

As mentioned previously, only the PIF is considered an earthquake source approximately $34 \mathrm{~km}$ in length and $14 \mathrm{~km}$ in width (Ozer Sozdinler et al., 2020; Karabulut et al., 2002). This fault zone is assumed to have the potential to generate a characteristic earthquake and rupture the entire fault. According to the Wells and Coppersmith (1994) scaling relation between fault area and magnitude (Eq. 1), this fault can generate a characteristic earthquake with magnitude varying between $M_{\mathrm{w}} 6.5$ and 7.1.

$M_{\mathrm{w}}=a+b \cdot \log (L \cdot W)$

In this equation, $a$ and $b$ are coefficients, which are 4.33 and 0.9 , respectively, $L$ is fault length, and $W$ is the fault width.

Displacement on the fault surface calculations is carried out for each randomly selected magnitude using the formulation of Aki (1966),

$D=\frac{M_{0}}{\mu A}=\frac{10^{\left(M_{\mathrm{w}}+6.07\right) \cdot 1.5}}{\mu A}$,

where $D$ is displacement on the fault surface, $M_{\mathrm{w}}$ is moment magnitude, $\mu$ is the shear modulus ( $\mu=30 \mathrm{GPa}$ ), and $A$ is the fault area.

Seismogenic thickness and the location of the earthquake is another important parameter required for earthquake and tsunami source. At first, the PIF zone is accepted as fully characteristic and an earthquake should rupture the entire fault area. Therefore, it is assumed that if the rupture starts at the center of the fault and continues in both directions, the fault will rupture entirely. For this reason, the locations of the earthquakes are accepted as the midpoint of the PIF zone for each earthquake scenario (Ozer Sozdinler et al., 2020).

For the seismogenic thickness, the seismic activity of the northern segment of NAFZ starts at the depth of $5 \mathrm{~km}$ (Karabulut et al., 2003). The bottom of the seismogenic thickness can be determined based on the aftershock activity of the 17 August 1999 İzmit earthquake. The earthquakes on the northern scarp of the Çınarcık basin are observed between 
the depths of 5 and $14 \mathrm{~km}$. The mechanism of events between the depth of 5 and $10 \mathrm{~km}$ shows the behavior of normal faulting. On the other hand, the strike-slip mechanism dominates the depths below 10 to $14 \mathrm{~km}$. As a result, seismic activity can be observed between the depths of 5 and $14 \mathrm{~km}$, and fault plane solutions show normal and strike-slip mechanisms in this area (Karabulut et al., 2002). Therefore, the depth of events varies between 5 and $14 \mathrm{~km}$ in MC simulations.

In time-independent earthquake occurrence models, probability of an event occurrence follows a Poisson distribution in a given period of time. Therefore, the result of this model does not vary in time. However, probability of an earthquake occurrence is based on the time that has passed since the occurrence of the last event and it follows a Brownian passage time (BPT), lognormal, or other probability distribution (Matthews et al., 2002; Ellsworth et al., 1999; Davis et al., 1989; Rikitake, 1974). In this model, in addition to the recurrence time of earthquakes, variability of the frequency of events and the elapsed time from the last characteristic event are the additional required information and the longer elapsed time causes an increase in probability of an event occurrence (Cramer et al., 2000; Petersen et al., 2007).

Calculation of probability in multi-segment ruptures and more complicated models includes the Gutenberg-Richter magnitude-frequency relationship (Gutenberg and Richter, 1944). The application of time-dependent models is based on a characteristic earthquake model, which assumes all large events occurring along a particular fault segment would have similar magnitudes, rupture area, and average displacements (Schwartz and Coppersmith, 1984). Therefore, this model is suitable for calculating the probability of occurrence of an earthquake on a single fault.

It should be noted that, in this study, PIF is considered to be the only source for the earthquake and tsunami. A timedependent probabilistic model is followed for the probability calculations because this probabilistic model allows us to consider only one fault instead of using multi-segment rupture scenarios through a characteristic earthquake model.

In the time-dependent approach, the BPT probability model is used to obtain the recurrence time probability of the earthquake in the fault segment. This model does not show a significant difference with the lognormal distribution except for consideration of very long elapsed times from the last characteristic event (Petersen et al., 2007). A characteristic event occurs when the load-state process reaches the failure threshold; an earthquake releases all energy loaded on the fault and then starts the new failure cycle. The time interval between consecutive earthquakes shows a Brownian passage time distribution and that can be useful to forecast long-term seismic events by generating a time-dependent model (Matthews et al., 2002). The Working Group on California Earthquake Probabilities (1999) and the Earthquake Research Committee (2001) have already implemented this time-dependent approach in the San Francisco Bay area and
Japan, respectively, for the prediction of long-term events (Petersen et al., 2007). This model depends on the time period passed since the last characteristic event and recurrence time of the earthquake. The probability density function for the BPT model (Matthews et al., 2002) is given by

$f\left(t, T_{\mathrm{r}}, \propto\right)=\left(\frac{T_{\mathrm{r}}}{2 \pi \alpha^{2} t^{3}}\right)^{1 / 2} \exp \left(\frac{\left(t-T_{\mathrm{r}}\right)^{1 / 2}}{2 T_{\mathrm{r}} \alpha^{2} t}\right)$,

where $t$ is the elapsed time from the last characteristic event and $\alpha$ is the aperiodicity (also known as the coefficient of variation). Aperiodicity defines the regularity of the expected characteristic earthquakes on the fault and varies between 0.3 and 0.7. This parameter, which is known as the parameter defining how much an expected characteristic earthquake occurs regularly or irregularly on any fault segment (Murru et al., 2016), was taken as 0.5 in this study (Parsons, 2004). The mean recurrence interval of earthquakes $\left(T_{\mathrm{r}}\right)$ can be defined as the ratio between the mean moment of repeating earthquakes (seismic moment) and the long-term moment accumulation rate on the fault (moment rate) (Ren and Zhang, 2013). Seismic moment can be obtained using the formulation of Kanamori (2004), and the moment rate of the fault is calculated from fault area and long-term slip rate of the fault (WGCEP, 2003).

$T_{\mathrm{r}}=\frac{M_{0}}{\dot{M}_{0}}=\frac{10^{\left(M_{\mathrm{w}}+6.07\right) \cdot 1.5}}{\mu V A}$

In this equation, $M_{\mathrm{w}}$ is moment magnitude, $\mu$ is the shear modulus, $V$ is long-term slip rate in millimeters per year, and $A$ is the fault area. The moment magnitude value in Eq. (4) was selected randomly using MC simulations. Thus, seismic moment $\left(M_{0}\right)$ and the mean recurrence time $\left(T_{\mathrm{r}}\right)$ were calculated for each earthquake scenario. Long-term slip rate is also selected as $17 \mathrm{~mm} \mathrm{yr}^{-1}$ for this equation (Ergintav et al., 2014).

Probability of the earthquake occurrence on the fault is calculated based on the probability density function approach. The probability of occurrence of an event in the next $\Delta T$ years, given that it has not occurred in the last $t$ years, is given by (Erdik et al., 2004)

$$
P(t, \Delta T)=\frac{\int_{t}^{t+\Delta T} f(t) \mathrm{d} t}{\int_{t}^{t+\infty} f(t) \mathrm{d} t} .
$$

In this case, probability of a characteristic earthquake was calculated using $\Delta T$ as 50 and 100 years. 


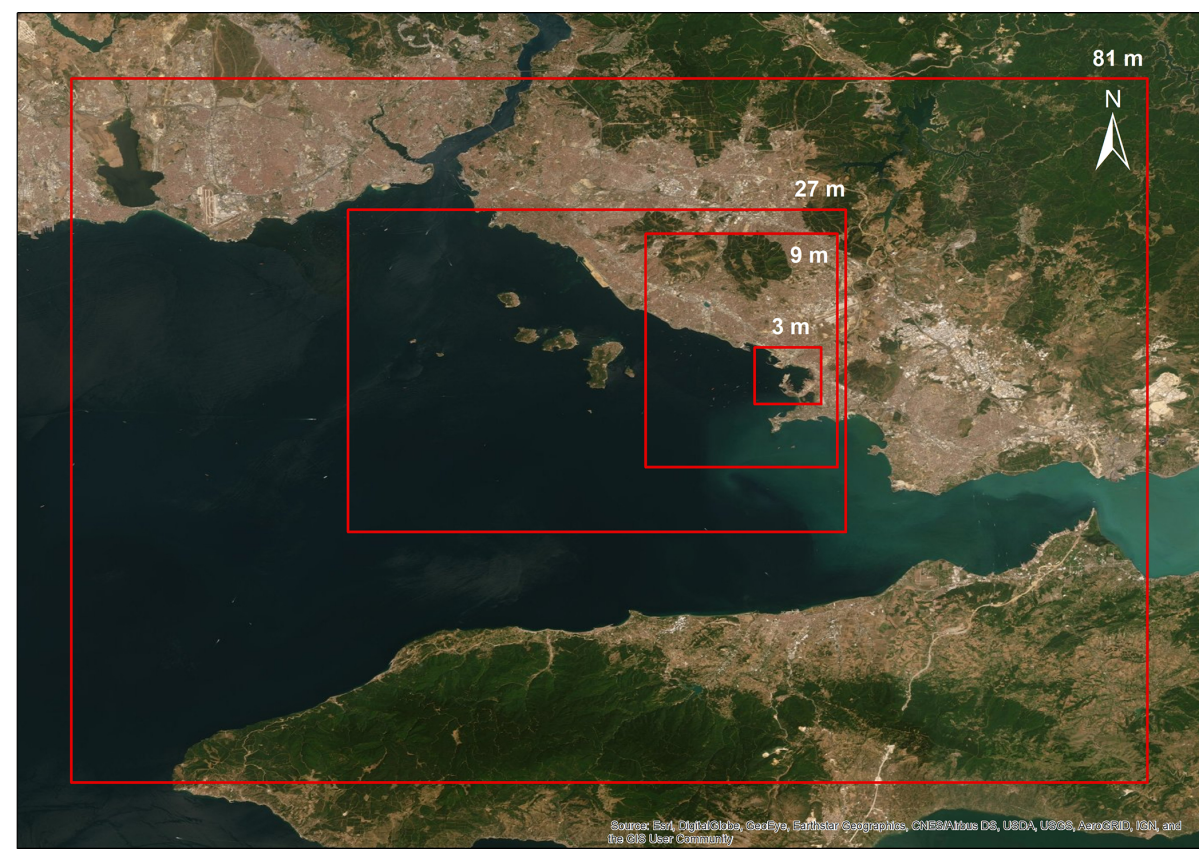

Figure 4. Nested domains for tsunami numerical modeling. Red rectangles show the limits of these domains. Grid size of these domains have a certain $1: 3$ ratio between each other (created using ArcMap version 10.5).

\section{Tsunami numerical modeling}

Tsunami simulations are performed for each earthquake in the synthetic catalogue using the tsunami numerical model NAMI DANCE (NAMI DANCE, 2011). The code is the user-friendly version of TUNAMI-N2 (Imamura et al., 2001) developed in $\mathrm{C}++$ language, which computes all fundamental parameters of tsunami motion in shallow water and in the inundation zone. It uses an explicit numerical solution of shallow water wave equations with the finite-difference technique and allows for better understanding of the effect of the tsunami waves (Shuto et al., 1990; Imamura, 1989). NAMI DANCE can solve both linear and nonlinear shallow water (NSW) equations with a selected coordinate system (Cartesian or spherical) and calculates the tsunami motion. Linear shallow water (LSW) equations are preferable in deep water because of reasonable computer time and memory, and they calculate the results at an acceptable error limit (Insel, 2009). NAMI DANCE is validated and verified using NOAA standards and criteria for tsunami currents and inundation (Synolakis et al., 2007, 2008). The numerical solutions of NAMI DANCE are also tested, validated and verified against analytical solutions, laboratory measurements, and field observations (NTHMP, 2015; Lynett et al., 2017; Velioglu, 2009).

NAMI DANCE calculates tsunami generation using Okada (1985) equations. In this study, water surface distribution of tsunami source (initial wave amplitude) is calculated with this method for 100 earthquakes of the synthetic earthquake catalogue prepared by MC simulations. As an ex- ample, Fig. 5 shows the initial water surface calculated due to one of 100 tsunami sources generated by MC simulations (Fig. 5).

Before starting tsunami simulations, the necessary inputs should be prepared precisely in order to obtain reliable results. Bathymetry-topography data are one of the most important inputs in NAMI DANCE that significantly effects the reliability of results, especially in the shallow water zone due to the nature of the NSW equations. NAMI DANCE can perform nested analyses under the condition that the grid sizes of the study domains have a certain $1: 3$ ratio between each other. Therefore, we generated four nested domains having the coarsest grid size as $81 \mathrm{~m}$ and the finest grid size as $3 \mathrm{~m}$ with a $1: 3$ ratio in the GIS environment. Bathymetric data for the biggest domain are the combination of the 30 arcsec resolution General Bathymetric Chart of the Oceans (GEBCO) and data produced by navigational charts in shallow zones. Topographic data, on the other hand, are at a high resolution, which is obtained from the Department of Housing and Urban Development of Istanbul Metropolitan Municipality digital elevation model (DEM) and vector data with resolution of 5 and $1 \mathrm{~m}$, respectively. The bathymetrytopography data in the smaller domains are the downscaled version of the $81 \mathrm{~m}$ grid bathymetry-topography data; however high-resolution digitized coastline and sea and land structures are also included in the data to generate the smallest grid domain of $3 \mathrm{~m}$ (Fig. 4).

The synthetic gauge point file is another required input of NAMI DANCE. In addition to the calculation of principal tsunami hydrodynamic parameters, the program can 


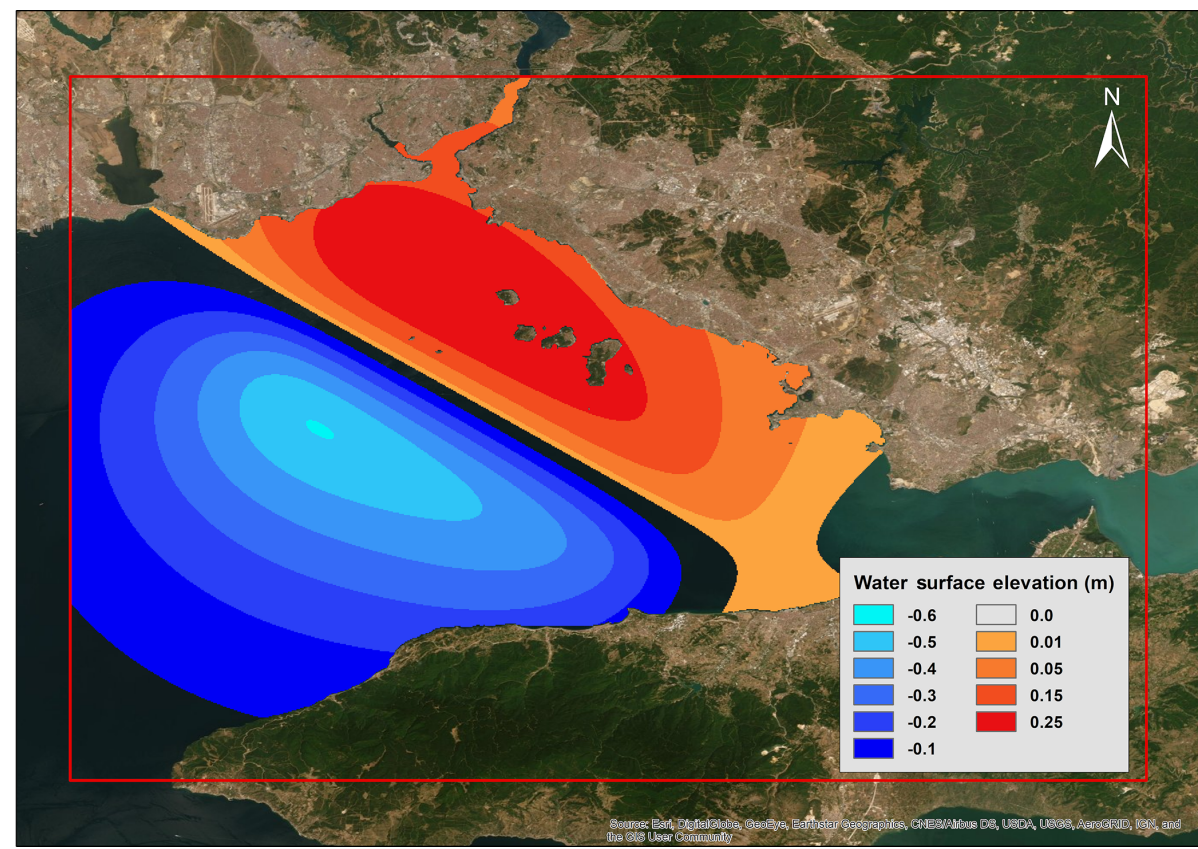

Figure 5. Initial water surface distribution of one of the 100 tsunami sources. The red frame indicates the boundary of the largest nested domain with an $81 \mathrm{~m}$ grid size (plotted using ArcMap version 10.5).

also calculate the change of water level, current velocity, and flow depth over time in every gauge point. Therefore, various gauge points are selected along the coast of nested domains, nearshore and offshore and close to some critical structures on land.

During the inundation of tsunami waves, current velocity is an important tsunami parameter in land and sea, especially in ports and bays. Strong current velocities may cause sea vessels to be dragged offshore by undertow or to ground inland. This parameter as well as tsunami wave amplitude, inundation depth, and Froude number can be calculated by NAMI DANCE. However, in this study, the results are represented based on only the probability of exceedance of threshold values for water surface elevation and inundation depth.

\section{Results and discussion}

In this study, tsunami hydrodynamic parameters are calculated in both the coarsest domain (whole Marmara Sea) and finest domain (Tuzla region). The main parameters focused in this study are the tsunami wave heights and inundation depths, and the results are shown in terms of probability of exceedance of threshold wave height and inundation depth values within the next 50 and 100 years. The situation for the next 500 years is not considered because the return period of the fault rupture is about 250 years, which means this fault generates at least one earthquake within the next 500 years. In other words, probability of exceedance for the next 500 years will be about $99 \%$.
We present the results of the PTHA for the Tuzla test site in terms of three different visualization categories for the next 50 and 100 years. First, distribution of probability of occurrence of the tsunami hydrodynamic parameters, which are minimum and maximum water surface elevation and inundation depth, is shown. Second, tsunami inundation maps that show the probability of exceedance of $0.3 \mathrm{~m}$ inundation depth for different time periods are generated for the Tuzla region in order to observe flooded areas and their probabilities clearly. Finally, the probability map of exceedance of $0.3 \mathrm{~m}$ wave heights at synthetic gauge points is represented as a bar chart.

\subsection{Probability of exceedance for the entire synthetic earthquake catalogue}

The graphics are generated to demonstrate the probabilities of occurrences corresponding to the minimum and maximum water surface elevations and inundation depth calculated from tsunami sources of each earthquake in the synthetic earthquake catalogue.

It should be noted that in the case of having same magnitude of earthquakes in two different earthquake scenarios of the catalogue, the probability of occurrences of these scenarios would be the same. However, since they would have different focal depths, the tsunami initial wave height calculated by Okada (1985) will be different, which results in the calculation of different hydrodynamic parameters. As a result, the graphs show different maximum water surface elevations having the same probability of occurrences. 

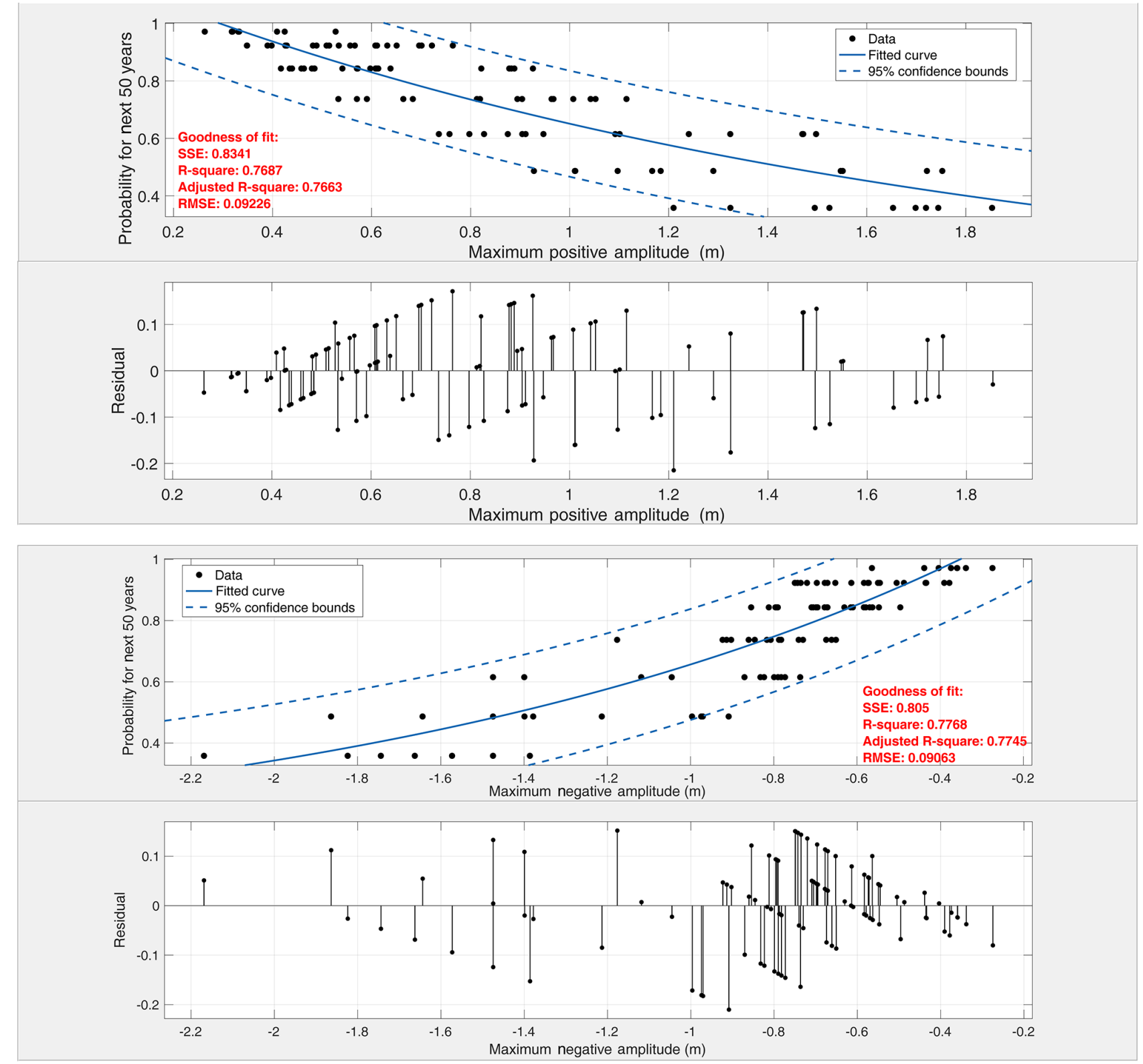

Figure 6.

In Fig. 6, graphics of probabilities of occurrences according to maximum and minimum water surface elevation (maximum water withdraw) and inundation depth for the next 50 years are represented. According to these graphs, tsunami wave heights up to $1 \mathrm{~m}$ and withdrawal of the waves around $1 \mathrm{~m}$ have approximately $65 \% \pm 15 \%$ probability of occurrence. The Tuzla region includes various shipyards, ports, and other important facilities. Therefore, the probability of the withdrawal of the water is as important as maximum water surface elevation. The $1 \mathrm{~m}$ height of wave withdrawal may cause the ships to be stranded at the ports and results in extreme financial losses as observed in the 20 July 2017 Bodrum-Kos earthquake and tsunami (Yalçıner et al., 2017).
The probability of having $1 \mathrm{~m}$ inundation depth, on the other hand, can be predicted as about $60 \% \pm 10 \%$. The residual of probability with respect to the fitted curve for each data point is demonstrated right after the percentage of probability with the \pm sign.

The situation for the next 100 years (Fig. 7) obviously shows that probability of occurrences would increase with time. The probability of exceedance of $1 \mathrm{~m}$ water surface elevation and $1 \mathrm{~m}$ wave withdrawal reaches up to $85 \% \pm 10 \%$. Probability of exceedance of inundation depth also changes significantly. The probability of exceedance of $1 \mathrm{~m}$ inundation depth is found to be around $80 \% \pm 10 \%$. 


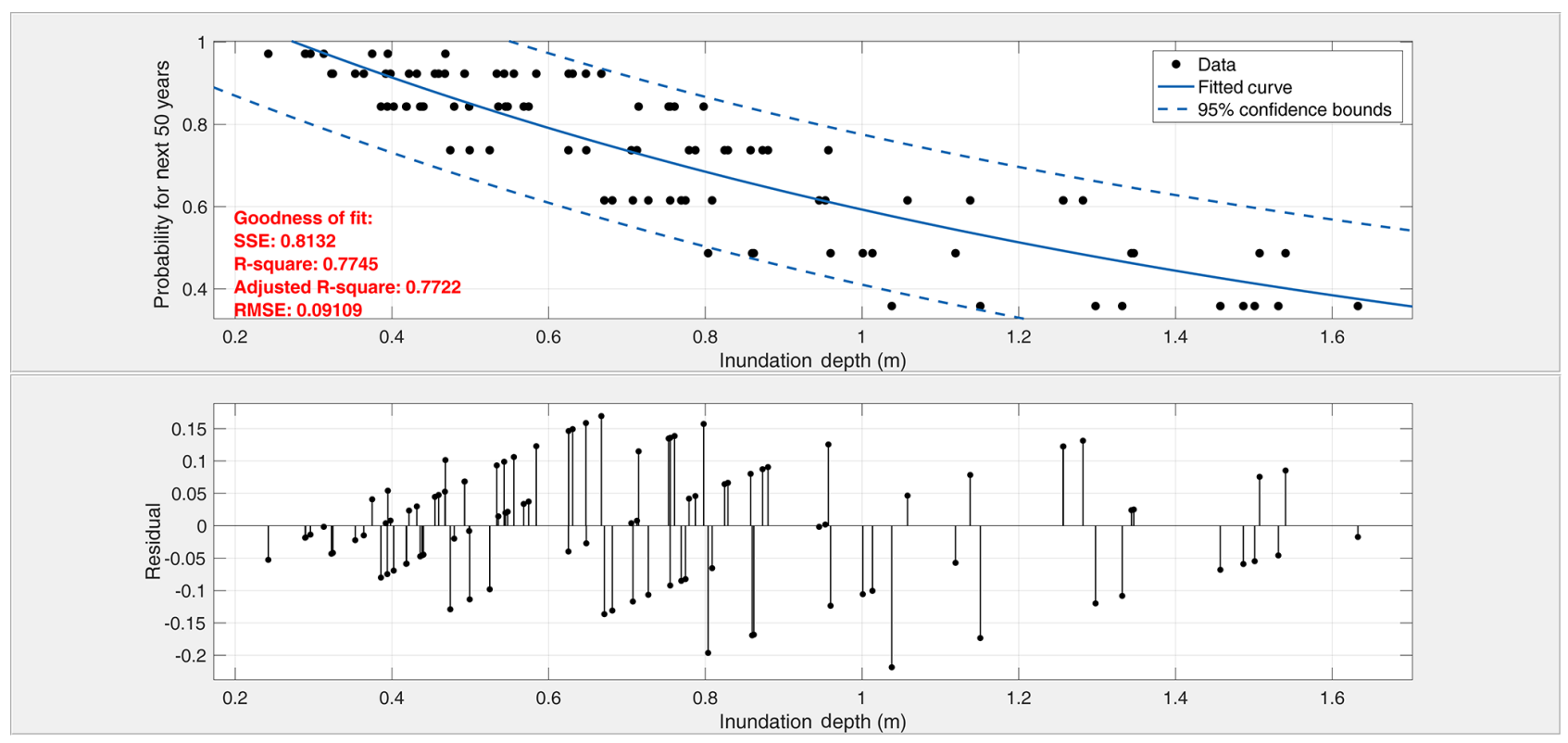

Figure 6. Probabilities of exceedance corresponding to maximum water surface elevation, minimum water surface elevation, and inundation depth for the next 50 years. Black dots represent the probability of exceedance of the tsunami hydrodynamic parameter for each event in the catalog. The blue line is the best fit curve to the data and the dashed blue line is the $95 \%$ confidence boundary of the fitted curve. The residual of the fit is represented for each probability curve.

Considering the results of the whole simulation, the worstcase earthquake scenario generated tsunami waves with maximum water surface elevation equal to $1.8 \mathrm{~m}$, minimum water surface elevation (maximum withdraw) equal to $-2.1 \mathrm{~m}$, and inundation depth equal to $1.6 \mathrm{~m}$. The probability of occurrence of this event is $35 \%$ for the next 50 years and $60 \%$ for the next 100 years.

\subsection{Probabilistic tsunami inundation maps for the Tuzla test site}

Inundation maps of the Tuzla domain are also prepared for the next 50 and 100 years in the GIS environment. Even if inundation depth is on the order of a few centimeters, it can lead to people being dragged by undertow in coastal regions due to the high current velocities of the waves (Jonkman and Penning-Rowsell, 2008). Therefore, these inundation maps have a great significance for understanding the flooded areas in the study domain and the amount of water penetrated inland.

Generation of inundation maps is based on the probability of exceedance of $0.3 \mathrm{~m}$ inundation depth. There are several studies in the literature proving both experimentally and numerically that tsunami waves with an order of $0.3 \mathrm{~m}$ height have the potential to crush a human body (Jonkman and Penning-Rowsell, 2008; Takagi et al., 2016). For this reason, only the earthquake scenarios that generated inundation depths larger than or equal to the $0.3 \mathrm{~m}$ threshold value are considered.
Inundation depth files, which are one of the outputs of the NAMI DANCE, are used for the calculation.

The inundation depth values at each grid node are replaced with the probability of occurrence of the respective earthquake scenario. We repeated this procedure for all earthquake scenarios, which has inundation depths larger than or equal to the $0.3 \mathrm{~m}$ threshold.

The mean (average) probability of occurrence is calculated at each grid node. Thus, the spatial distribution of probability of exceedance of $0.3 \mathrm{~m}$ inundation depth in the inundation zone is obtained for a specific time interval (Fig. 8).

Figure 8 shows the inundation maps of Tuzla shipyard for the next 50 and 100 years. Most of the area in the Tuzla shipyard region has a probability of exceedance between $10 \%$ and $20 \%$ for the next 50 and 100 years. However, some places in the northern and southern parts of the area and inside the bay show larger than $75 \%$ probability of inundation within the next 100 years. Maximum inundation distance is observed at around $60 \mathrm{~m}$ at the test site.

In Fig. 9, probabilistic inundation maps of one of the most important facilities in the study region are represented for the next 50 and 100 years. The area has high potential to be exposed to tsunami waves with a probability larger than $50 \%$ for the next 50 years. In 100 years, this probability increases and varies between $75 \%$ and $90 \%$. No significant inundation zone is observed along the coast of the seawall and the peninsula. This may be due to the high ground elevation of these zones. Tsunami waves are inundated up to $45 \mathrm{~m}$ inside the small bay. This inundation distance could cause severe dam- 

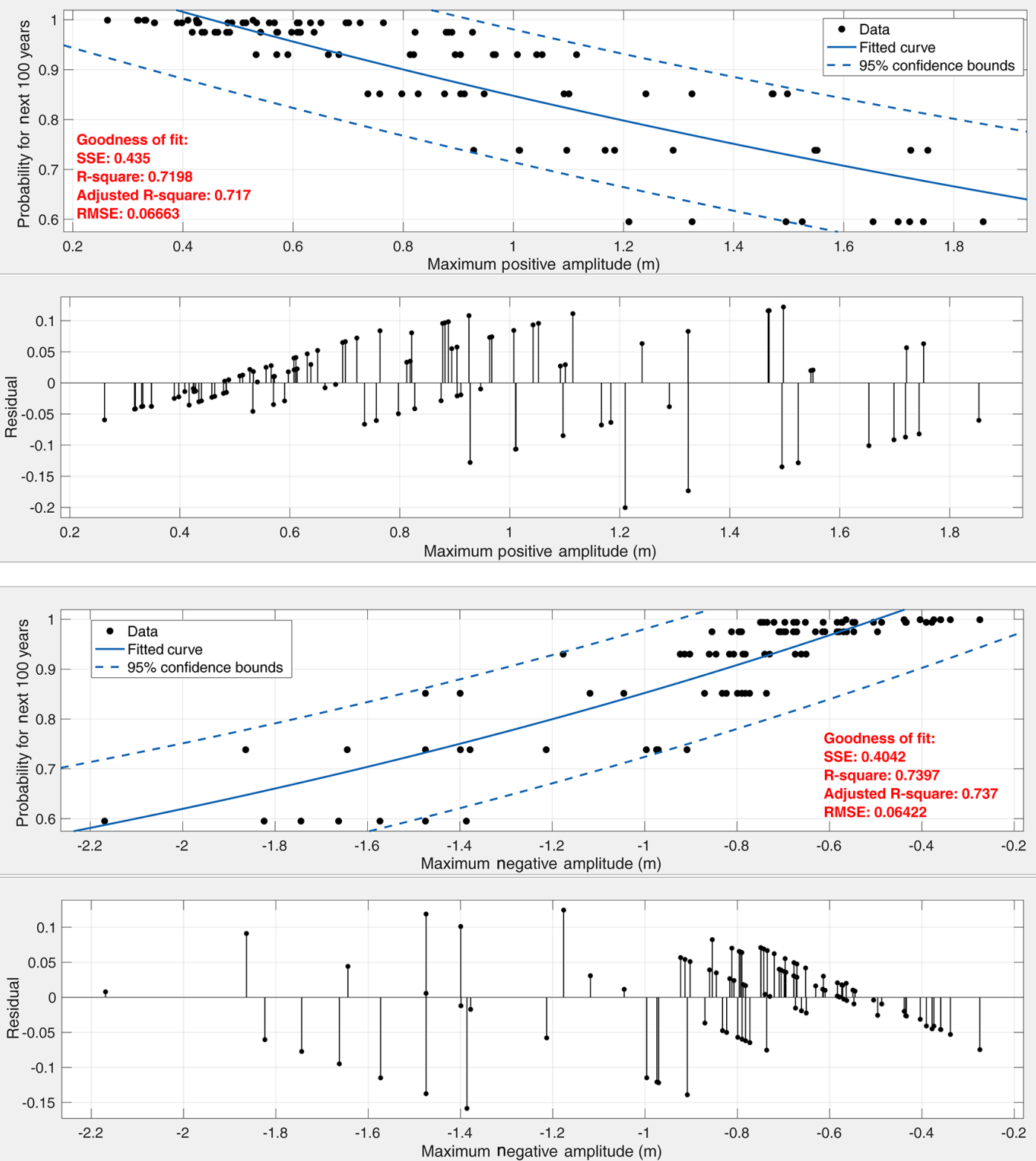

Figure 7.

age to the shipyard and other constructions if corresponding current velocities are also significant.

In the next figure (Fig. 10), the southern part of the Tuzla shipyard is seen according to probabilities of inundation for the next 50 and 100 years. Very limited area in the coastal zone is inundated with the probability between $30 \%$ and $50 \%$ within the next 50 years. The probability decreases up to $10 \%$ at some inner locations from the coastline. For 100year recurrence time, the situation is almost the same. Only minor parts of the region in the south approach the $75 \%-$ $90 \%$ probability of exceedance of $0.3 \mathrm{~m}$ inundation depth threshold. The maximum inundation distance is calculated at about $60 \mathrm{~m}$. The inundated region does not include any im- portant facility or structure, and the effect of the tsunami will be minimal. The inundation distance decreases to $10 \mathrm{~m}$ in the other parts of the region.

The region indicated in Fig. 11 is located inside the bay and includes a large part of the shipyard area. This area includes lots of large and small piers and ship construction facilities. The situation is more or less the same as the previous region (Fig. 9). The probability of having larger than $0.3 \mathrm{~m}$ inundation depth changes between $30 \%$ and $50 \%$ within the next 50 years, while only a few places show $75 \%-90 \%$ probability for the next 100 years along the coast. Moreover, the maximum inundation distance is calculated as $25 \mathrm{~m}$ for this zone. Even if the probability of inundation is low, these zones 


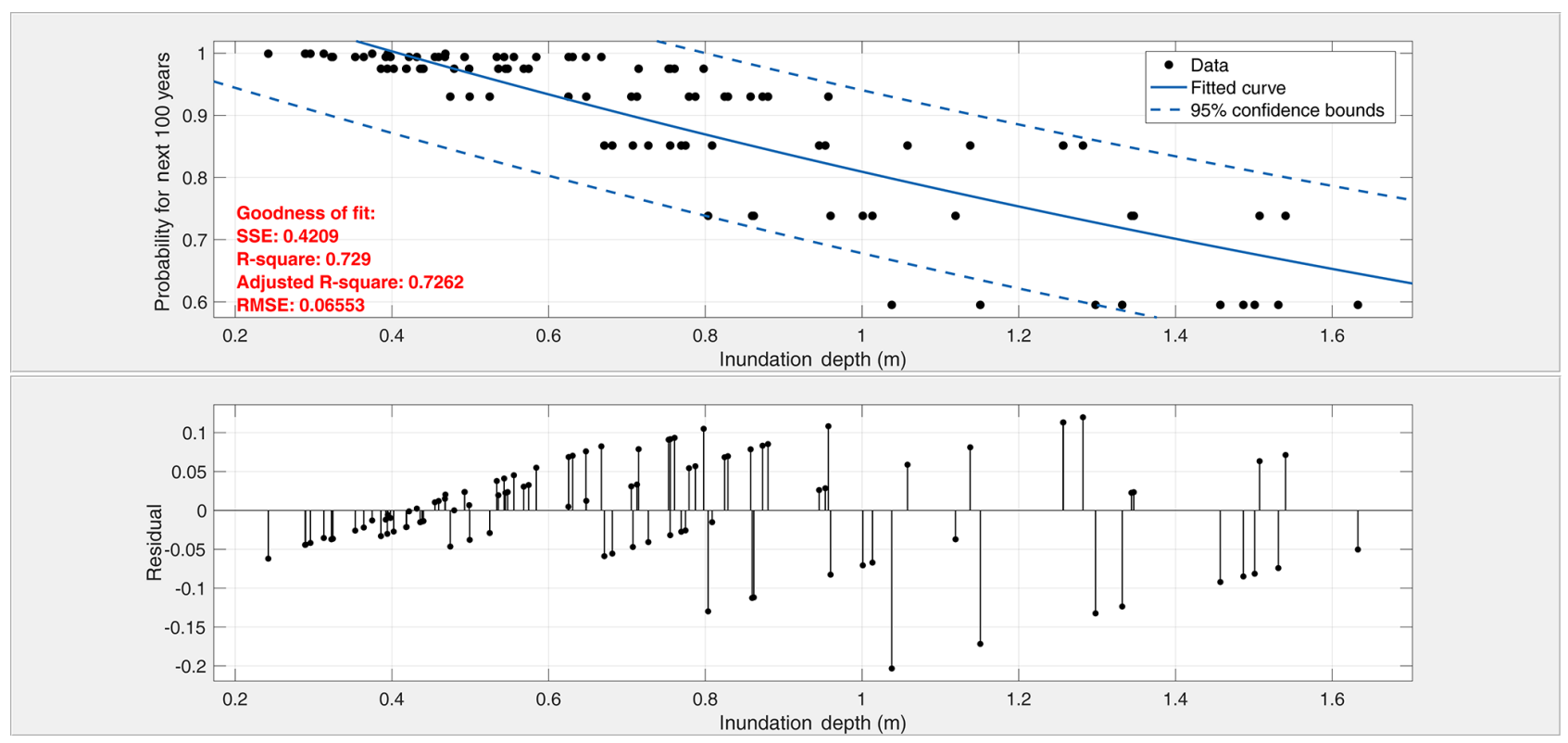

Figure 7. Probabilities of exceedance corresponding to maximum water surface elevation, minimum water surface elevation, and inundation depth for the next 100 years. Black dots represent the probability of exceedance of the tsunami hydrodynamic parameter for each event in the catalog. The blue line is the best fit curve to the data and the dashed blue line is the $95 \%$ confidence boundary of the fitted curve. The residual of the fit is represented for each probability curve.

should be taken into consideration before constructing a new structure.

\subsection{Synthetic gauges}

Finally, the probability of exceedance of $0.3 \mathrm{~m}$ wave heights at synthetic gauge points is presented by bar charts to consider the nearshore effect of tsunami waves along the western coast of Istanbul. Because of the closeness to the fault zone, the southeast coasts of the city are under threat of significant tsunami damage. Similar to the method applied during the preparation of probabilistic inundation maps, the earthquake scenarios with wave heights at synthetic gauge points larger than or equal to $0.3 \mathrm{~m}$ are selected and replaced with the probability of each scenario according to wave heights, and after that the average probabilities at each synthetic gauge point are obtained accordingly.

Figure 12 demonstrates the probability of exceedance of $0.3 \mathrm{~m}$ wave height at synthetic gauge points, which are about $350 \mathrm{~m}$ apart from each other, along the western coast of Istanbul within the next 50 and 100 years. The probability increases while color scale changes from green to purple. According to this figure, minimum probability of exceedance is shown as $75 \%$ at some points. Except for a few of the 228 synthetic gauge points, all points have larger than $90 \%$ probability of exceedance of $0.3 \mathrm{~m}$ wave height within the next 50 years.

This condition is very serious since there are so many residential areas and important spots such as ports and recreational facilities in this region. The minimum probability of occurrence, which can generate tsunami waves with at least $0.3 \mathrm{~m}$ wave heights, reaches up to $90 \%$ for the next 100 year time period. However, $95 \%$ probability of exceedance of $0.3 \mathrm{~m}$ wave height dominates the region for this timescale.

\subsection{Uncertainties}

PTHA studies include some uncertainties because of the rare occurrence of the large events. Quantification of these uncertainties generally includes the mixture of empirical analyses and subjective judgment.

Uncertainties of PTHA can be divided into two: as aleatory and epistemic variability. Aleatoric uncertainty is the natural randomness of the physical process. Including more data in the analyses does not contribute to the reduction of the aleatoric uncertainty. However, knowledge about the modeling process may decrease this unpredictability. The occurrence time of the earthquake is one of the most fundamental aleatory variables in PTHA. This parameter is generally assumed to be a time-independent variable. However, in this study we used a time-dependent probability model, which reduces the uncertainty on this parameter. The mechanism of the source is considered to be another aleatory variable for PTHA studies. The majority of earthquakes around the world occur at well-defined plate boundaries. However, some unidentified low-activity intraplate faults exist, which were recently included in PTHA studies (Selva et al., 2016). Moreover, the fault volume, which is used in scaling relations to calculate the source magnitude, is another aleatory term. Although homogenous slip distribution is a common imple- 

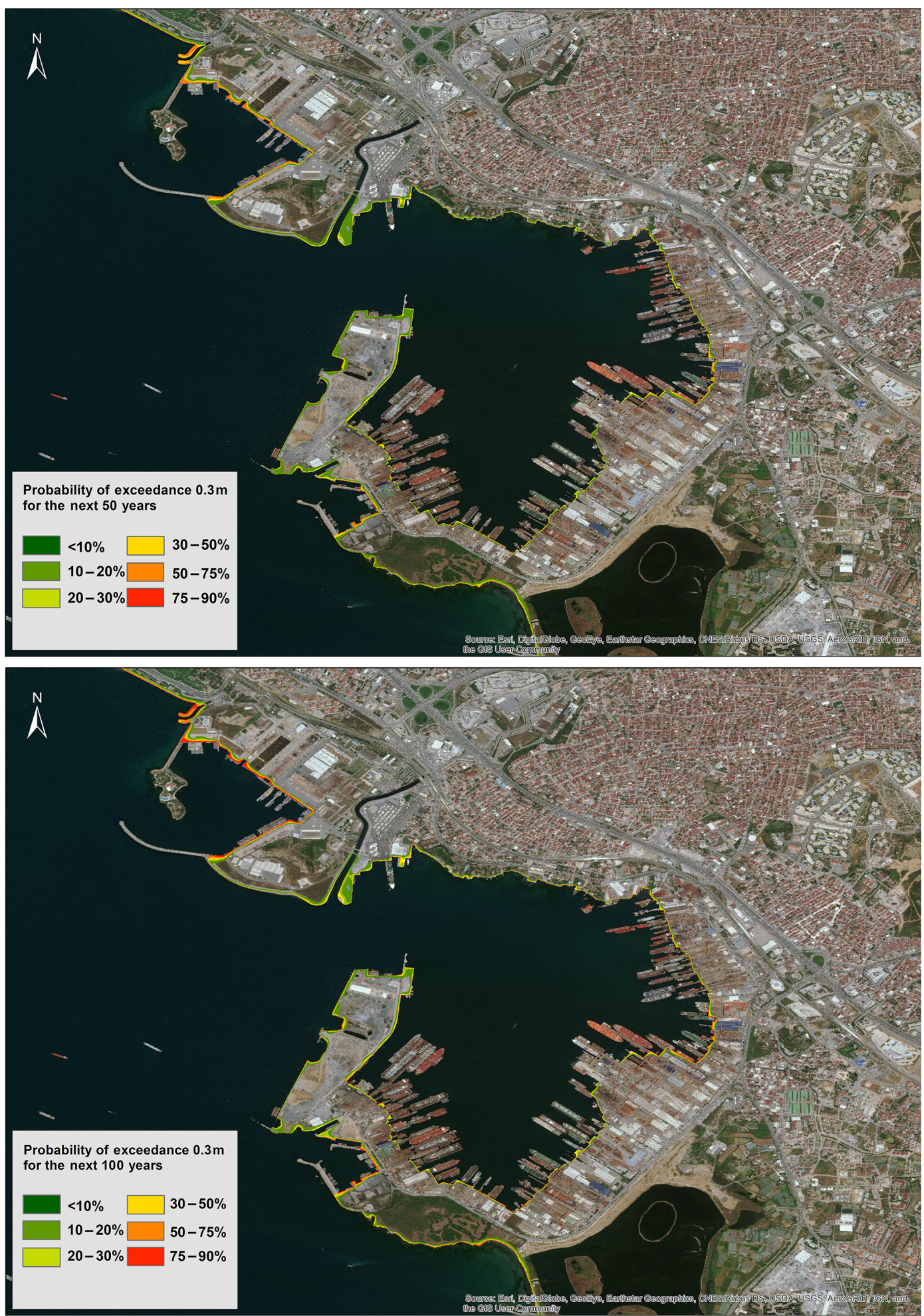

Figure 8. Probabilistic tsunami inundation maps for the Tuzla study domain representing the probability of exceedance of $0.3 \mathrm{~m}$ inundation depth within the next 50 and 100 years. Change of colors from green to red represents the increasing probability of exceedance (created using ArcMap version 10.5). 

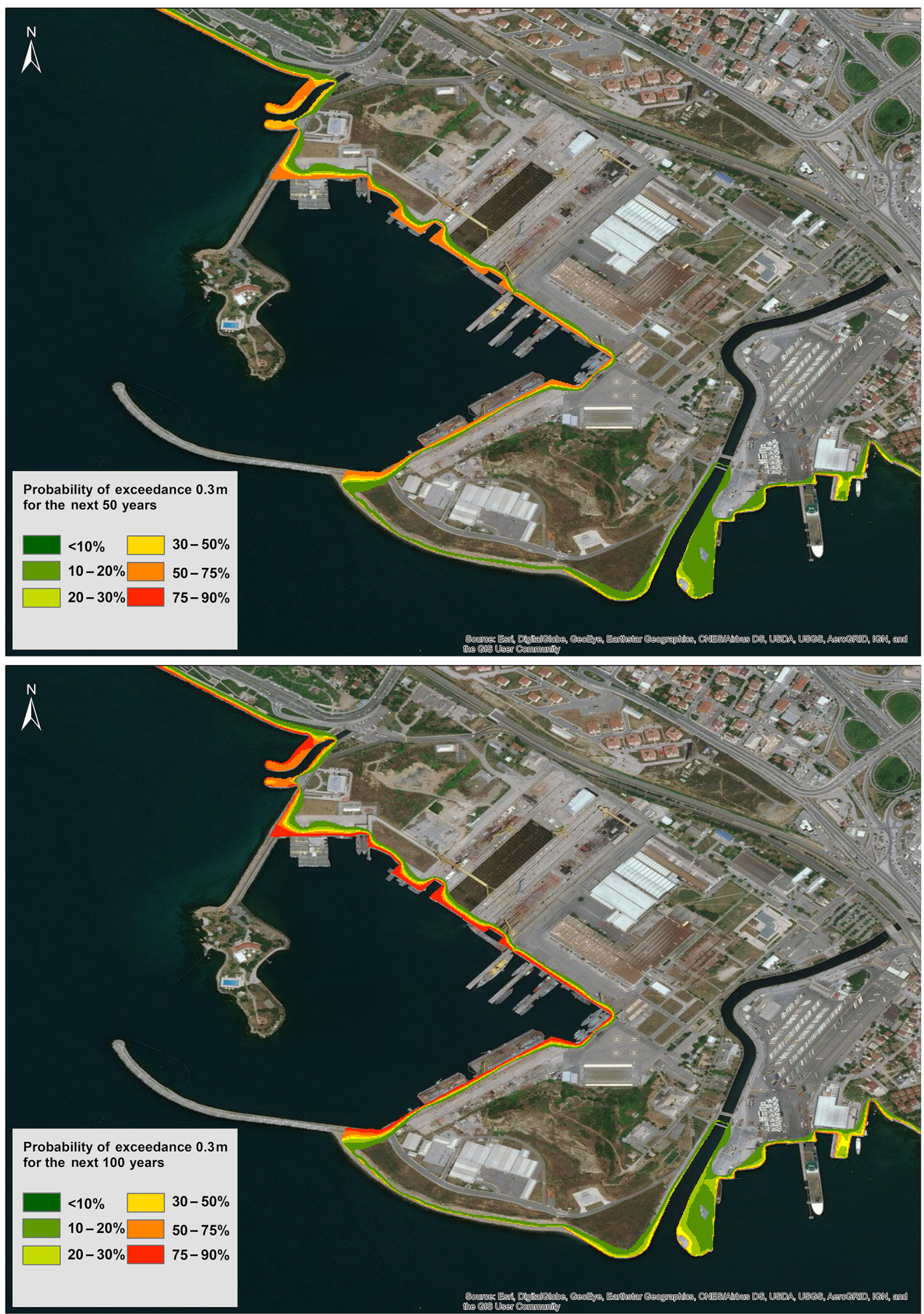

Figure 9. Probabilistic tsunami inundation maps of the northern part of the Tuzla study domain representing the probability of exceedance of $0.3 \mathrm{~m}$ inundation depth for the next 50 and 100 years. Change of colors from green to red represents the increasing probability of exceedance (created using ArcMap version 10.5). 

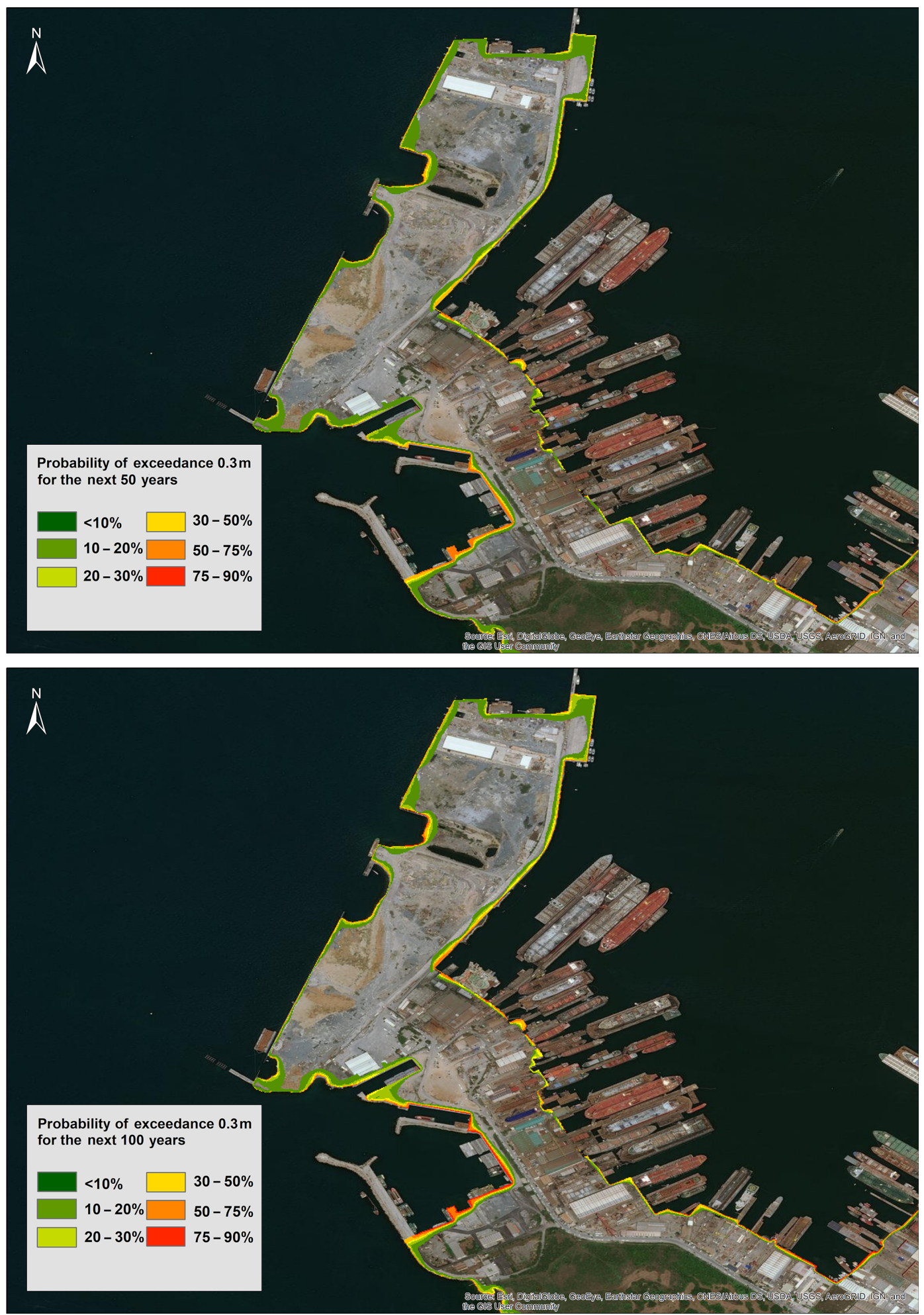

Figure 10. Probabilistic tsunami inundation maps for the southern part of the Tuzla study domain representing the probability of exceedance of $0.3 \mathrm{~m}$ inundation depth for the next 50 and 100 years. Change of colors from green to red represents the increasing probability of exceedance (created using ArcMap version 10.5). 

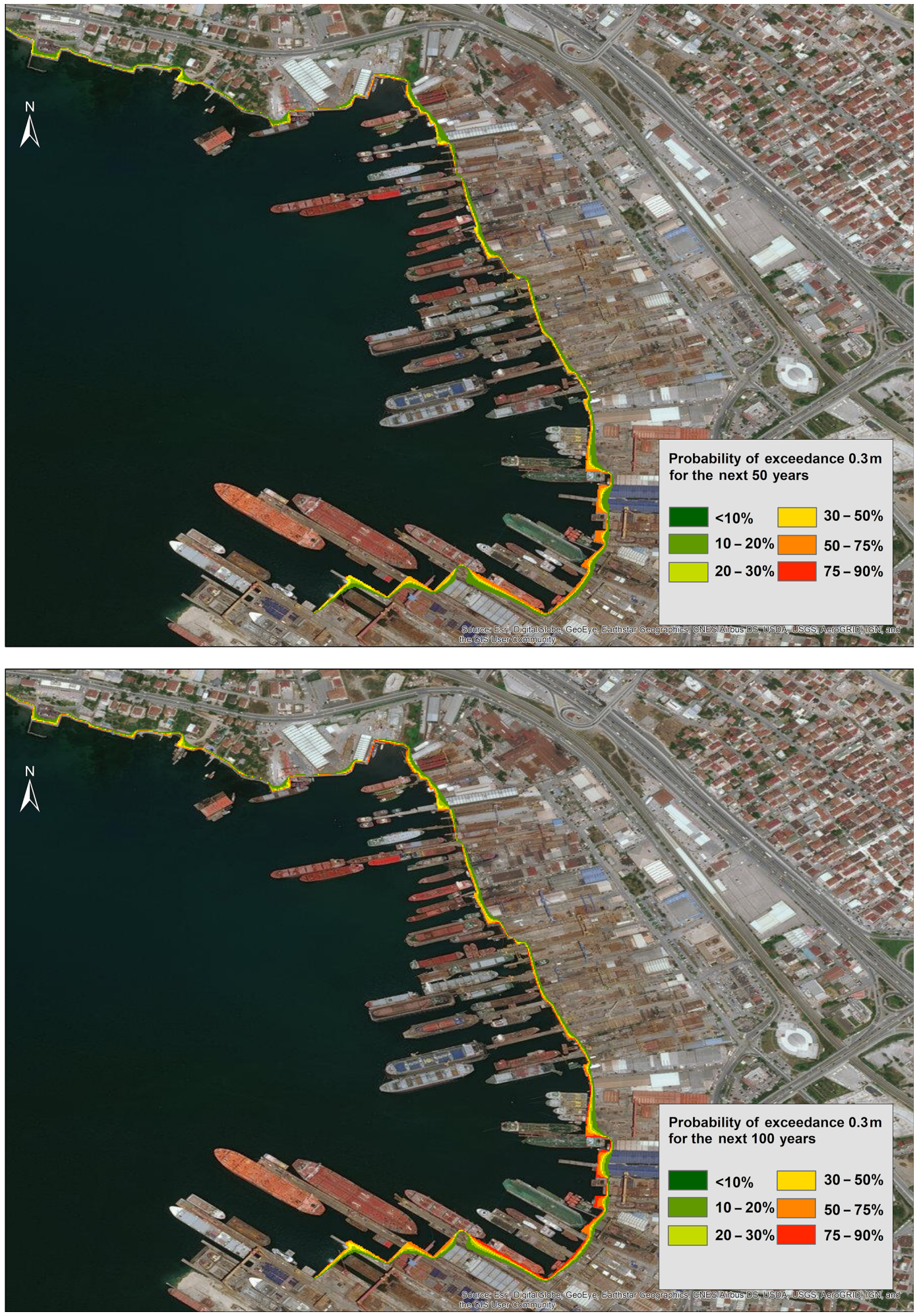

Figure 11. Probabilistic tsunami inundation maps of the shipyard area in the Tuzla study domain representing the probability of exceedance of $0.3 \mathrm{~m}$ inundation depth for the next 50 and 100 years. Change of colors from green to red represents the increasing probability of exceedance (created using ArcMap version 10.5). 

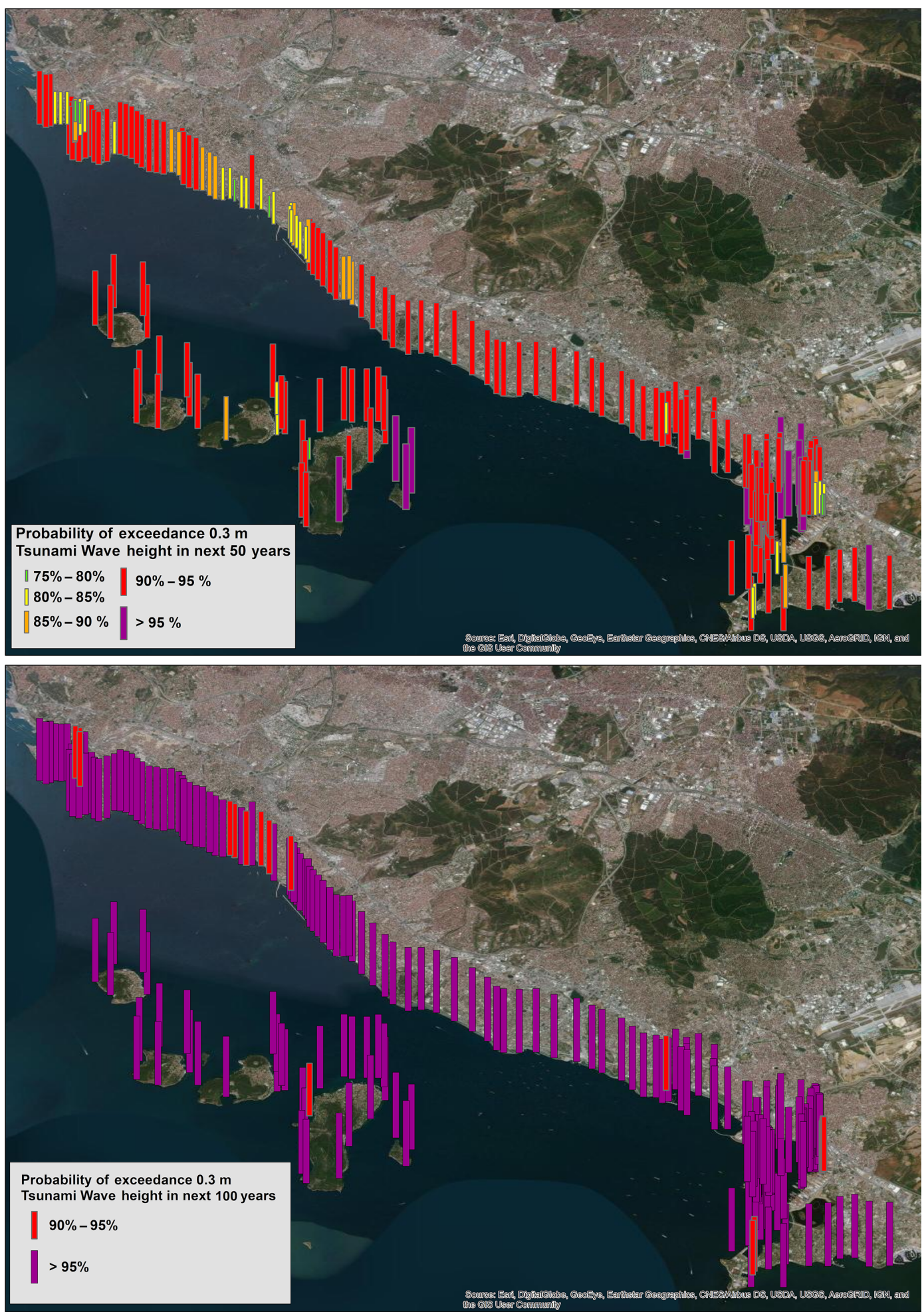

Figure 12. Probability of exceedance of the $0.3 \mathrm{~m}$ tsunami wave height within the next 50 and 100 years at synthetic gauge points. The yellow rectangles show the Tuzla study domain; change of colors from purple to green on the bars represents the decreasing probability of exceedance (created using ArcMap version 10.5). 
mentation in PTHA, slip distribution of large events does not show homogenous behavior. Therefore, definition of asperities on the fault is another aleatoric variable which should be considered. Tsunami numerical modeling, itself, is also another aleatoric variable since they do not show correlation with real observations, which are more variable than earthquake scenarios incorporated in PTHA (Grezio et al., 2017). The aleatory variable affects the results because it is incorporated directly into the hazard calculations (Abrahamson and Bommer, 2005).

Epistemic uncertainty, on the other hand, consists of the lack of knowledge of the physical process and data. Segmentation of the fault system is one of the epistemic variables since it is not certain where the rupture will be generated and which segments will be triggered. In addition, there are many different scaling relations, which cause another epistemic uncertainty, between the fault area and magnitude. It is also important for tsunami generation whether the fault rupture reaches the surface or not. Thus, updip and downdip limits of the fault rupture can be considered another epistemic variable (Grezio et al., 2017). Accurate probability distributions of input cannot be known. For example, one cannot assume that probability of occurrence of an event follows Poisson distribution. However, return periods of events do not simply fit this distribution (Gonzalez et al., 2013). Unlike aleatoric uncertainty, epistemic uncertainty can be decreased when more information is available (Godinho, 2007). Different techniques, such as logic tree, the Bayesian method, etc., have been developed to reduce these uncertainties.

In this study, a probabilistic model is established based on the characteristic fault model of PIF, which is a segment of NAF, one of the best studied fault zones in the world. It is also assumed that the entire fault area is ruptured, reaching the surface and generating a homogenous slip for each event. The maximum magnitude range of the fault is calculated with the Wells and Coppersmith (1994) scaling relation. All these assumptions naturally include uncertainties which are naturally reflected in this PTHA study. In addition, MC simulation itself also includes uncertainty as being performed 100 times to create synthetic earthquake scenarios. The effect of uncertainty in the aperiodicity parameter also exists and can be reduced by including different parameters for MC simulation. Therefore, the tsunami hydrodynamic parameters associated with the probability of occurrence of the corresponding scenario preserve the same uncertainty.

\section{Conclusion}

In this study, time-dependent PTHA is performed in the Tuzla region of Istanbul for the purpose of understanding the probability of having tsunami inundation after the PIF rupture. The study combines tsunami numerical modeling with a probabilistic approach, which is modified by probabilistic seismic hazard analysis. Probability calculations have been done based on the time-dependent BPT model, which depends on the time period passed since the last characteristic event and the recurrence time of the earthquake. After that, the synthetic earthquake catalogue is generated using the MC simulation technique, and tsunami numerical modeling was performed depending on this earthquake catalogue using NAMI DANCE code in a GPU environment.

Results of this PTHA study were presented in three different ways for the next 50 and 100 years. The first one was the graphs showing the change of probability with the maximum and minimum water surface elevation and inundation depth for different time intervals. Secondly, the probabilistic tsunami inundation maps are generated for the Tuzla region. Finally, the probability maps of exceedance of $0.3 \mathrm{~m}$ wave heights at synthetic gauge points are represented with bar charts.

The main results of this study can be summarized as follows.

- According to the distribution of probability with respect to tsunami hydrodynamic parameters, the probability of exceedance of $1 \mathrm{~m}$ maximum positive and negative water surface elevation is $65 \%$ within the next 50 years. The probability for $1 \mathrm{~m}$ inundation depth is $60 \%$.

- Considering probabilities for the next 100 years, $85 \%$ probability of exceedance of $1 \mathrm{~m}$ was calculated. For $1 \mathrm{~m}$ inundation depth, probability of exceedance of about $80 \%$ is obtained.

- As a result of the whole simulation, 1.8, -2.1, and $1.6 \mathrm{~m}$ were calculated for maximum and minimum water surface elevation and inundation depth, with the probability of $35 \%$ for the next 50 years and $60 \%$ for the next 100 years.

- Inundation maps indicate that inundation of tsunami waves that are equal to or larger than $0.3 \mathrm{~m}$ have probability mostly higher than $10 \%$ and $20 \%$ for the next 50 years and 100 years, respectively. The probability of occurrence of $0.3 \mathrm{~m}$ inundation depth was calculated as a maximum of $75 \%$ for the next 100 years. Maximum inundation distance is calculated as $60 \mathrm{~m}$ and observed in the southern part of the finest $3 \mathrm{~m}$ grid-sized study area.

- Probabilistic results for the exceedance of $0.3 \mathrm{~m}$ wave height at synthetic gauge points demonstrate that only a few of them have a probability between $75 \%$ and $85 \%$; however several points have more than $90 \%$ probability for the next 50 years. Probability of exceedance increases by more than $95 \%$ for the next 100 years.

The tsunami impact of the PIF rupture along the Tuzla coast is very important as proposed by the results of this study. However, as further steps of this study, PTHA can be done for the other critical test sites along the Marmara Sea that 
are close to the PIF segment. In addition, it is also advantageous to consider the other fault segments, with their various rupture combinations and complex rupture probabilities in Marmara Sea, as further studies. Previously in the framework of the MARSITE project, tsunami arrival times and maximum wave amplitudes were calculated along the coast of the Marmara Sea using different earthquake scenarios, and a tsunami scenario database was obtained with a deterministic approach (Ozer Sozdinler et al., 2020). Results of this study show that arrival time of tsunami waves is very short in Marmara Sea for most of the scenarios, which complicates the tsunami early warning operations and evacuation actions. However, due to the short arrival times of the first tsunami waves along the Marmara coast, the tsunami inundation scenario databases would be of great importance in such conditions. It would be the best option for the decision makers and civil protection authorities to also have the inundation maps prepared with a probabilistic approach in order to realize the possibility of exceedance of selected threshold inundation depth for certain critical coastal locations.

This study shows a methodology for PTHA with a timedependent probabilistic model using only one fault (PIF) as the earthquake and tsunami source. Furthermore, this study can be developed including some faults connected to the PIF in both time-dependent and time-independent probability calculations, and BPT probability can be combined with static Coulomb stress changes on the faults. The BPT model can also be improved by including different aperiodicity parameters. The probability of occurrence of earthquakes is the main focus of this study to perform tsunami hazard analyses. However, submarine landslides are other critically important sources for tsunami generation in the Marmara Sea. Probabilities of sliding areas and the sliding volumes can be considered in the analyses. Submarine landslide-generated tsunamis can be coupled with the earthquake-triggered tsunamis in order to obtain integrated PTHA in the Marmara Sea.

Data availability. Data of scenarios used in tsunami numerical modeling, inputs for probabilistic tsunami inundation map for 50 and 100 years, and ${ }^{*} . \mathrm{kml}$ files for probability of exceedance in bar charts can be accessed at https://doi.org/10.6084/m9.figshare.12033789 (last access: 27 March 2020) (Bayraktar, 2020). Further information can be made available upon request to the corresponding author.

Author contributions. HBB performed background research, constructed the database, carried out tsunami simulations, mapped the tsunami inundation maps, and wrote the paper. COS supervised the entire study in all stages and contributed to writing the paper.

Competing interests. The authors declare that they have no conflict of interest.
Acknowledgements. The authors would like to acknowledge the project MARSITE - New Directions in Seismic Hazard assessment through Focused Earth Observation in the Marmara Supersite (FP7ENV.2012 6.4-2, grant 308417) and the SATREPS project. The authors would like to especially thank Ahmet Cevdet Yalçıner for his valuable feedback and effort during this study and Bora Yalçıner and Andrey Zaitsev for their great support in the development and improvement of the NAMI DANCE numerical code. We would also like to thank Öcal Necmioğlu, Maura Murru, Giuseppe Falcone, Semih Ergintav, Sinan Akkar, Mine Demircioğlu, and Mustafa Erdik for their valuable support and feedback. The Generic Mapping Tools (GMT; Wessel and Smith, 1998) was used for plotting a tectonic map of Turkey and bathymetric map of the Marmara fault system. Other maps throughout this paper were created using ArcGIS ${ }^{\circledR}$ software by Esri. ArcGIS ${ }^{\circledR}$ and ArcMap ${ }^{\mathrm{TM}}$ are the intellectual property of Esri and are used herein under license. Copyright (C) Esri. All rights reserved. For more information about Esri ${ }^{\circledR}$ software, please visit https://www.esri.com/en-us/home (last access: 16 February 2020).

Financial support. This research has been supported by the project MARSITE - New Directions in Seismic Hazard assessment through Focused Earth Observation in the Marmara Supersite (grant no. 308417$)$.

Review statement. This paper was edited by Ira Didenkulova and reviewed by two anonymous referees.

\section{References}

Abrahamson, N. A. and Bommer, J. J.: Probability and uncertainty in seismic hazard analysis, Earthq. Spect., 21, 603-607, https://doi.org/10.1193/1.1899158, 2005.

Aki, K.: Asperities, barriers, characteristic earthquakes and strong motion prediction, J. Geophys. Res.-Solid, 89, 5867-5872, https://doi.org/10.1029/JB089iB07p05867, 1984.

Aki, K.: Generation and propagation of $\mathrm{G}$ waves from the Niigata Earthquake of June 16 1964. Part 2. Estimation of earthquake movement, released energy, and stress-strain drop from the G wave spectrum, Bull. Earthq. Res. Inst., 44, 73-88, 1966.

Aksu, A. E., Calon, T. J., Hiscott, R. N., and Yasar, D.: Anatomy of the North Anatolian Fault Zone in the Marmara Sea, Western Turkey: extensional basins above a continental transform, GSA Today, 10, 3-7, 2000.

Allen, C. R.: The tectonic environments of seismically active and inactive areas along the San Andreas fault system, Stanford University Publications, Geol. Sci., 11, 70-80, 1968.

Alpar, B. and Yaltırak, C.: Characteristic features of the North Anatolian Fault in the eastern Marmara region and its tectonic evolution, Mar. Geol., 190, 329-350, https://doi.org/10.1016/S00253227(02)00353-5, 2002.

Altınok, Y. and Alpar, B.: Marmara Island earthquakes, of 1265 and 1935; Turkey, Nat. Hazards Earth Syst. Sci., 6, 999-1006, https://doi.org/10.5194/nhess-6-999-2006, 2006.

Altınok, Y., Alpar, B., and Yaltırak, C.: Şarköy-Mürefte 1912 earthquake's tsunami, extension of the associated faulting 
in the Marmara Sea, Turkey, J. Seismol., 7, 329-346, https://doi.org/10.1023/A:1024581022222, 2003.

Altinok, Y., Alpar, B., Özer, N., and Aykurt, H.: Revision of the tsunami catalogue affecting Turkish coasts and surrounding regions, Nat. Hazards Earth Syst. Sci., 11, 273-291, https://doi.org/10.5194/nhess-11-273-2011, 2011.

Ambraseys, N.: The seismic activity of the Marmara Sea region over the last 2000 years, Bull. Seismol. Soc. Am., 92, 1-18, https://doi.org/10.1785/0120000843, 2002.

Ambraseys, N. N. and Jackson, J. A.: Seismicity of the Sea of Marmara (Turkey) since 1500, Geophys. J. Int., 141, F1-F6, https://doi.org/10.1046/j.1365-246x.2000.00137.x, 2000.

Ambraseys, N. N. N. and Finkel, C. F.: Seismicity of Turkey and Adjacent Areas: A Historical Review 1500-1800, MS Eren, Istanbul, Turkey, 1995.

Annaka, T., Satake, K., Sakakiyama, T., Yanagisawa, K., and Shuto, N.: Logic-tree approach for probabilistic tsunami hazard analysis and its applications to the Japanese coasts, in: Tsunami and its hazards in the indian and pacific oceans, Birkhäuser, Basel, 577592, https://doi.org/10.1007/978-3-7643-8364-0_17, 2007.

Armijo, R., Meyer, B., Hubert, A., and Barka, A.: Westward propagation of the North Anatolian fault into the northern Aegean: Timing and kinematics, Geology, 27, 267-270, https://doi.org/10.1130/00917613(1999)027<0267:WPOTNA>2.3.CO;2, 1999.

Armijo, R., Meyer, B., Navarro, S., King, G., and Barka, A.: Asymmetric slip partitioning in the Sea of Marmara pullapart: A clue to propagation processes of the North Anatolian fault?, Terra Nova, 14, 80-86, https://doi.org/10.1046/j.13653121.2002.00397.x, 2002.

Armijo, R., Pondard, N., Meyer, B., Uçarkus, G., de Lépinay, B. M., Malavieille, J., Dominguez, S., Gustcher, M. A., Schmidt, S., Beck, C., Cagatay, N., Çakır, Z., Imren, C., Eris, K., Natalin, B., Özalaybey, S., Tolun, L., Lefèvre, I., Seeber, L., Gasperini, L., Rangin, C., Emre, O., and Sarikavak, K.: Submarine fault scarps in the Sea of Marmara pull-apart (North Anatolian Fault): Implications for seismic hazard in Istanbul, Geochem. Geophy., Geosy., 6, Q06009, https://doi.org/10.1029/2004GC000896, 2005.

Aytore, B., Yalciner, A. C., Zaytsev, A., Cankaya, Z. C., and Suzen, M. L.: Assessment of tsunami resilience of Haydarpaşa Port in the Sea of Marmara by high-resolution numerical modeling, Earth Planets Space, 68, 139, https://doi.org/10.1186/s40623016-0508-z, 2016.

Barka, A.: The 17 august 1999 Izmit earthquake, Science, 285, 1858-1859, https://doi.org/10.1126/science.285.5435.1858, 1999.

Bayraktar, H. $\quad$ B.: $\quad$ Tuzla-PTHA, https://doi.org/10.6084/m9.figshare.12033789, 2020.

Bohnhoff, M., Bulut, F., Dresen, G., Malin, P. E., Eken, T., and Aktar, M.: An earthquake gap south of Istanbul, Nat. Commun., 4, 1999, https://doi.org/10.1038/ncomms2999, 2013.

Cankaya, Z. C., Suzen, M. L., Yalciner, A. C., Kolat, C., Zaytsev, A., and Aytore, B.: A new GIS-based tsunami risk evaluation: MeTHuVA (METU tsunami human vulnerability assessment) at Yenikap1, Istanbul, Earth Planets Space, 68, 133, https://doi.org/10.1186/s40623-016-0507-0, 2016.

Cramer, C. H., Petersen, M. D., Cao, T., Toppozada, T. R., and Reichle, M.: A time-dependent probabilistic seismic-hazard model for California, Bull. Seismol. Soc. Am., 90, 1-21, https://doi.org/10.1785/0119980087, 2000.

Davis, P. M., Jackson, D. D., and Kagan, Y. Y.: The longer it has been since the last earthquake, the longer the expected time till the next?, Bull. Seismol. Soc. Am., 79, 1439-1456, 1989.

Earthquake Research Committee: Evaluation method and its application for the probability of long-term earthquke occurrence, Headquarters for Earthquake Research Promotion, Tokyo, 2001.

Ellsworth, W. L., Matthews, M. V., Nadeau, R. M., Nishenko, S. P., Reasenberg, P. A., and Simpson, R. W.: A physically-based earthquake recurrence model for estimation of long-term earthquake probabilities, US Geol. Surv. Open-File Rept. 99, US Geological Survey, Menlo Park, CA, 23 pp., 1999.

Emre, Ö., Duman, T. Y., Özalp, S., Elmacı, H., Olgun, Ş., and Şaroğlu, F.: Active fault map of Turkey with explanatory text, General Directorate of Mineral Research and Exploration Special Publication Series, Ankara, Turkey, p. 30, 2013.

Erdik, M., Demircioglu, M., Sesetyan, K., Durukal, E., and Siyahi, B.: Earthquake hazard in Marmara region, Turkey, Soil Dynam. Earthq. Eng., 24, 605-631, https://doi.org/10.1016/j.soildyn.2004.04.003, 2004.

Ergintav, S., Reilinger, R. E., Çakmak, R., Floyd, M., Cakir, Z., Doğan, U., and Özener, H.: Istanbul's earthquake hot spots: Geodetic constraints on strain accumulation along faults in the Marmara seismic gap, Geophys. Res. Lett., 41, 5783-5788, https://doi.org/10.1002/2014GL060985, 2014.

Flerit, F., Armijo, R., King, G. C. P., Meyer, B., and Barka, A.: Slip partitioning in the Sea of Marmara pull-apart determined from GPS velocity vectors, Geophys. J. Int., 154, 1-7, https://doi.org/10.1046/j.1365-246X.2003.01899.x, 2003.

Flerit, F., Armijo, R., King, G., and Meyer, B.: The mechanical interaction between the propagating North Anatolian Fault and the back-arc extension in the Aegean, Earth Planet. Sc. Lett., 224, 347-362, https://doi.org/10.1016/j.eps1.2004.05.028, 2004.

Gasperini, L., Polonia, A., Çağatay, M. N., Bortoluzzi, G., and Ferrante, V.: Geological slip rates along the North Anatolian Fault in the Marmara region, Tectonics, 30, TC6001, https://doi.org/10.1029/2011TC002906, 2011.

Geist, E. L. and Lynett, P. J.: Source processes for the probabilistic assessment of tsunami hazards, Oceanography, 27, 86-93, https://doi.org/10.5670/oceanog.2014.43, 2014

Geist, E. L. and Parsons, T.: Probabilistic analysis of tsunami hazards, Nat. Hazards, 37, 277-314, https://doi.org/10.1007/s11069005-4646-z, 2006.

Goda, K. and De Risi, R.: Multi-hazard loss estimation for shaking and tsunami using stochastic rupture sources, Int. J. Disast. Risk Reduct., 28, 539-554, https://doi.org/10.1016/j.ijdrr.2018.01.002, 2018.

Godinho, J.: Probabilistic Seismic Hazard Analysis an Introduction to Theoretical Basis and Applied Methodology, Msc thesis, University of Patras, Greece, 2007.

González, F. I., Geist, E. L., Jaffe, B., Kânoğlu, U., Mofjeld, H., Synolakis, C. E., Titov, V. V., Arcas, D., Bellomo, D., Carlton, D., Horning, T., Johnson, J., Newman, J., Parsons, T., Peters, R., Peterson, C., Priest, G., Venturato, A., Weber, J., Wong, F., and Yalciner, A.: Probabilistic tsunami hazard assessment at seaside, Oregon, for near-and far-field seismic sources, J. Geophys. Res.Oceans, 114, C11023, https://doi.org/10.1029/2008JC005132, 2009. 
Gonzalez, F. I., LeVeque, R. J., and Adams, L. M.: Probabilistic Tsunami Hazard Assessment (PTHA) for Crescent City, CA, Final Report for Phase I, University of Washington, Department of Applied Mathmatics, Washington, available at: http://hdl.handle. net/1773/25916 (last access: 18 April 2019), 2013.

Grezio, A., Babeyko, A., Baptista, M. A., Behrens, J., Costa, A., Davies, G., Geist, E. L., Glimsdal, S., González, F. I., Griffin, J., Harbitz, C. B., LeVeque, R. J., Lorito, S., Løvholt, F., Omira, R., Mueller, C., Paris, R., Parsons, T., Polet, J., Power, W., Selva, J., Sørensen, M. B., Thio, H. K., and Harbitz, C. B.: Probabilistic tsunami hazard analysis: Multiple sources and global applications, Rev. Geophys., 55, 1158-1198, https://doi.org/10.1002/2017RG000579, 2017.

Guler, H. G., Arikawa, T., Oei, T., and Yalciner, A. C.: Performance of rubble mound breakwaters under tsunami attack, a case study: Haydarpasa Port, Istanbul, Turkey, Coast. Eng., 104, 4353, https://doi.org/10.1016/j.coastaleng.2015.07.007, 2015.

Gutenberg, B. and Richter, C. F.: Frequency of earthquakes in California, Bull. Seismol. Soc. Am., 34, 185-188, 1944.

Hancilar, U.: Identification of elements at risk for a credible tsunami event for Istanbul, Nat. Hazards Earth Syst. Sci., 12, 107-119, https://doi.org/10.5194/nhess-12-107-2012, 2012.

Hébert, H., Schindele, F., Altinok, Y., Alpar, B., and Gazioglu, C.: Tsunami hazard in the Marmara Sea (Turkey): a numerical approach to discuss active faulting and impact on the Istanbul coastal areas, Mar. Geol., 215, 23-43, https://doi.org/10.1016/j.margeo.2004.11.006,2005.

Hergert, T. and Heidbach, O.: Slip-rate variability and distributed deformation in the Marmara Sea fault system, Nat. Geosci., 3, 132-135, https://doi.org/10.1038/ngeo739, 2010.

Hergert, T., Heidbach, O., Bécel, A., and Laigle, M.: Geomechanical model of the Marmara Sea region - I. 3-D contemporary kinematics, Geophys. J. Int., 185, 1073-1089, https://doi.org/10.1111/j.1365-246X.2011.04991.x, 2011.

Horspool, N., Pranantyo, I., Griffin, J., Latief, H., Natawidjaja, D. H., Kongko, W., Cipta, A., Bustaman, B., Anugrah, S. D., and Thio, H. K.: A probabilistic tsunami hazard assessment for Indonesia, Nat. Hazards Earth Syst. Sci., 14, 3105-3122, https://doi.org/10.5194/nhess-14-3105-2014, 2014.

Imamura, F.: Tsunami Numerical Simulation with the Staggered Leap-frog Scheme (Numerical code of TUNAMI-N1), School of Civil Engineering, Asian Institute Technical and Disaster Control Research Center, Tohoku University, Tohoku, 1989.

Imamura, F., Yalçıner, A. C., and Özyurt, G.: TUNAMI-N2: Tsunami Modelling Manual, available at: http://www.tsunami. civil.tohoku.ac.jp/hokusai3/J/projects/manual-ver-3.1.pdf (last access: 20 March 2019), 2001.

Imren, C., Le Pichon, X., Rangin, C., Demirbağ, E., Ecevitoğlu, B., and Görür, N.: The North Anatolian Fault within the Sea of Marmara: a new interpretation based on multi-channel seismic and multi-beam bathymetry data, Earth Planet. Sc. Lett., 186, 143158, https://doi.org/10.1016/S0012-821X(01)00241-2, 2001.

Insel, I.: The Effects of the Material Density and Dimensions of the Landslide on the Generated Tsunamis, Msc Thesis, Middle East Technical University, Ankara, Turkey, 2009.

Jonkman, S. N. and Penning-Rowsell, E.: Human instability in Flood Flows, J. Am. Water Resour. Assoc., 44, 1208-1218, https://doi.org/10.1111/j.1752-1688.2008.00217.x, 2008.
Kanamori, H.: The diversity of the physics of earthquakes, Proc. Japan Acad. Ser. B, 80, 297-316, https://doi.org/10.2183/pjab.80.297, 2004.

Kaneko, F.: A simulation analysis of possible tsunami affecting the Istanbul coast, Turkey, in: International Workshop on Tsunami Hazard Assessment and Management in Bangladesh, 21-22 January 2009, Dhaka, Bangladesh, 2009.

Karabulut, H., Bouin, M. P., Bouchon, M., Dietrich, M., Cornou, C., and Aktar, M.: The seismicity in the eastern Marmara Sea after the 17 August 1999 Izmit earthquake, Bull. Seismol. Soc. Am., 92, 387-393, https://doi.org/10.1785/0120000820, 2002.

Karabulut, H., Özalaybey, S., Taymaz, T., Aktar, M., Selvi, O., and Kocaoğlu, A.: A tomographic image of the shallow crustal structure in the Eastern Marmara, Geophys. Res. Lett, 30, 2277, https://doi.org/10.1029/2003GL018074, 2003.

KOERI - Kandilli Observatory and Earthquake Research Institute: Bosphorus Univercity: Bogazici University Kandilli Observatory And Earthquake Research Institute, International Federation of Digital Seismograph Networks, Dataset/Seismic Network, https://doi.org/10.7914/SN/KO, 2001.

Latcharote, P., Suppasri, A., Imamura, F., Aytore, B., and Yalciner, A. C.: Possible worst-case tsunami scenarios around the Marmara Sea from combined earthquake and landslide sources, in: Global Tsunami Science: Past and Future, Vol. I, Birkhäuser, Cham, 3823-3846, https://doi.org/10.1007/s00024-016-1411-z, 2016.

Le Pichon, X., Şengör, A. M. C., Demirbağ, E., Rangin, C., Imren, C., Armijo, R., Görür, N., Çağatay, N., de Lépinay, B. M., Meyer, B., Saatç1lar, R., and Tok, B.: The active main Marmara fault, Earth Planet. Sc. Lett., 192, 595-616, https://doi.org/10.1016/S0012-821X(01)00449-6, 2001.

Le Pichon, X., Chamot-Rooke, N., Rangin, C., and Sengör, A. M. C.: The North Anatolian fault in the sea of Marmara, J. Geophys. Res.-Solid, 108, 2179, https://doi.org/10.1029/2002JB001862, 2003.

Le Pichon, X., Imren, C., Rangin, C., Şengör, A. C., and Siyako, M.: The South Marmara Fault, Int. J. Earth Sci., 103, 219-231, https://doi.org/10.1007/s00531-013-0950-0, 2014.

Le Pichon, X., Şengör, A. C., Kende, J., İmren, C., Henry, P., Grall, C., and Karabulut, H.: Propagation of a strike-slip plate boundary within an extensional environment: the westward propagation of the North Anatolian Fault, Can. J. Earth Sci., 53, 1416-1439, https://doi.org/10.1139/cjes-2015-0129, 2015.

Lorito, S., Selva, J., Basili, R., Romano, F., Tiberti, M. M., and Piatanesi, A.: Probabilistic hazard for seismically induced tsunamis: accuracy and feasibility of inundation maps, Geophys. J. Int., 200, 574-588, https://doi.org/10.1093/gji/ggu408, 2015.

Løvholt, F., Glimsdal, S., Harbitz, C. B., Zamora, N., Nadim, F., Peduzzi, P., and Smebye, H.: Tsunami hazard and exposure on the global scale, Earth-Sci. Rev., 110, 58-73, https://doi.org/10.1016/j.earscirev.2011.10.002, 2012.

Løvholt, F., Griffin, J., and Salgado-Gálvez, M.: Tsunami hazard and risk assessment at a global scale, Encyclopedia of complexity and systems science, 1-34, https://doi.org/10.1007/978-3-64227737-5_642-1, 2015.

Lynett, P. J., Gately, K., Wilson, R., Montoya, L., Arcas, D., Aytore, B., and David, C. G.: Inter-model analysis of tsunami-induced coastal currents, Ocean Model., 114, 14-32, https://doi.org/10.1016/j.ocemod.2017.04.003, 2017. 
Matthews, M. V., Ellsworth, W. L., and Reasenberg, P. A.: A Brownian model for recurrent earthquakes, Bull. Seismol. Soc. Am., 92, 2233-2250, https://doi.org/10.1785/0120010267, 2002.

McNeill, L. C., Mille, A., Minshull, T. A., Bull, J. M., Kenyon, N. H., and Ivanov, M.: Extension of the North Anatolian Fault into the North Aegean Trough: Evidence for transtension, strain partitioning, and analogues for Sea of Marmara basin models, Tectonics, 23, TC2016, https://doi.org/10.1029/2002TC001490, 2004.

Meade, B. J., Hager, B. H., McClusky, S. C., Reilinger, R. E., Ergintav, S., Lenk, O., Barka, A., and Özener, H.: Estimates of seismic potential in the Marmara Sea region from block models of secular deformation constrained by Global Positioning System measurements, Bull. Seismol. Soc. Am., 92, 208-215, https://doi.org/10.1785/0120000837, 2002.

Murru, M., Akinci, A., Falcone, G., Pucci, S., Console, R., and Parsons, T.: $M \geq 7$ earthquake rupture forecast and time-dependent probability for the Sea of Marmara region Turkey, J. Geophys. Res.-Solid, 121, 2679-2707, https://doi.org/10.1002/2015JB012595, 2016.

NAMI DANCE: Manual of Numerical Code NAMI DANCE, available at: http://namidance.ce.metu.edu.tr (last access: 12 October 2018), 2011.

NTHMP: Proceedings and Results of the National Tsunami Hazard Mitigation Program 2015 Tsunami Current Modeling Workshop, Portland, Oregon, 2015.

Oglesby, D. D. and Mai, P. M.: Fault geometry, rupture dynamics and ground motion from potential earthquakes on the North Anatolian Fault under the Sea of Marmara, Geophys. J. Int., 188, 1071-1087, https://doi.org/10.1111/j.1365-246X.2011.05289.x, 2012.

Okada, Y.: Surface deformation due to shear and tensile faults in a half-space, Bull. Seismol. Soc. Am., 75, 1135-1154, 1985.

Okay, A. I., Demirbağ, E., Kurt, H., Okay, N., and Kuşçu, İ: An active, deep marine strike-slip basin along the North Anatolian fault in Turkey, Tectonics, 18, 129-147, https://doi.org/10.1029/1998TC900017, 1999.

Ozer Sozdinler, C., Necmioglu, O., Bayraktar, H. B., and Ozel, N. M.: Tectonic Origin Tsunami Scenario Database for the Marmara Region, Nat. Hazards Earth Syst. Sci. Discuss., https://doi.org/10.5194/nhess-2019-186, in review, 2019.

Parsons, T.: Recalculated probability of $M \geq 7$ earthquakes beneath the Sea of Marmara, Turkey, J. Geophys. Res.-Solid, 109, B05304, https://doi.org/10.1029/2003JB002667, 2004.

Petersen, M. D., Cao, T., Campbell, K. W., and Frankel, A. D.: Time-independent and time-dependent seismic hazard assessment for the State of California: Uniform California Earthquake Rupture Forecast Model 1.0, Seismol. Res. Lett., 78, 99-109, https://doi.org/10.1785/gssrl.78.1.99, 2007.

Pondard, N., Armijo, R., King, G. C., Meyer, B., and Flerit, F.: Fault interactions in the Sea of Marmara pull-apart (North Anatolian Fault): earthquake clustering and propagating earthquake sequences, Geophys. J. Int., 171, 1185-1197, https://doi.org/10.1111/j.1365-246X.2007.03580.x, 2007.

Reilinger, R., McClusky, S., Vernant, P., Lawrence, S., Ergintav, S., Cakmak, R., Ozener, H., Kadirov, F., Guliev, I., Stepanyan, R., Nadariya, M., Hahubia, G., Mahmoud, S., Sakr, K. ArRajehi, A., Paradissis, D., Al-Aydrus, A., Prilepin, M., Guseva, T., Evren, E., Dmitrotsa, A., Filikov, S. V.,
Gomez, F., Al-Ghazzi, R., and Karam, G. : GPS constraints on continental deformation in the Africa-Arabia-Eurasia continental collision zone and implications for the dynamics of plate interactions, J. Geophys. Res.-Solid, 111, B05411, https://doi.org/10.1029/2005JB004051, 2006.

Ren, J. and Zhang, S.: Estimation of recurrence interval of large earthquakes on the Central Longmen Shan fault zone based on seismic moment accumulation/release model, Scient. World J., 2013, 458341, https://doi.org/10.1155/2013/458341, 2013.

Rikitake, T.: Probability of earthquake occurrence as estimated from crustal strain, Tectonophysics, 23, 299-312, https://doi.org/10.1016/0040-1951(74)90029-8, 1974.

Ryall, A., Slemmons, D. B., and Gedney, L. D.: Seismicity, tectonism, and surface faulting in the western United States during historic time, Bull. Seismol. Soc. Am., 56, 1105-1135, 1966.

Schwartz, D. P. and Coppersmith, K. J.: Fault behavior and characteristic earthquakes: Examples from the Wasatch and San Andreas fault zones, J. Geophys. Res.-Solid, 89, 5681-5698, https://doi.org/10.1029/JB089iB07p05681, 1984.

Selva, J., Tonini, R., Molinari, I., Tiberti, M. M., Romano, F., Grezio, A., and Lorito, S.: Quantification of source uncertainties in seismic probabilistic tsunami hazard analysis (SPTHA), Geophys. J. Int., 205, 1780-1803, https://doi.org/10.1093/gji/ggw107, 2016.

Şengör, A. C., Grall, C., İmren, C., Le Pichon, X., Görür, N., Henry, P., and Siyako, M.: The geometry of the North Anatolian transform fault in the Sea of Marmara and its temporal evolution: implications for the development of intracontinental transform faults, Can. J. Earth Sci., 51, 222-242, https://doi.org/10.1139/cjes-2013-0160, 2014.

Shuto, N., Goto, C., and Imamura, F.: Numerical simulation as a means of warning for near-field tsunamis, Coast. Eng. Japan, 33, 173-193, https://doi.org/10.1080/05785634.1990.11924532, 1990.

Sørensen, M. B., Spada, M., Babeyko, A., Wiemer, S., and Grünthal, G.: Probabilistic tsunami hazard in the Mediterranean Sea, J. Geophys. Res.-Solid, 117, B01305, https://doi.org/10.1029/2010JB008169, 2012.

Stein, R. S., Barka, A. A., and Dieterich, J. H.: Progressive failure on the North Anatolian fault since 1939 by earthquake stress triggering, Geophys. J. Int., 128, 594-604, https://doi.org/10.1111/j.1365-246X.1997.tb05321.x, 1997.

Synolakis, C. E., Bernard, E. N., Titov, V. V., Kânoğlu, U., and González, F. I.: Standards, Criteria, and Procedures for NOAA Evaluation of Tsunami Numerical Models, NOAA OAR Special Report, Contribution No. 3053, NOAA/OAR/PMEL, Seattle, Washington, 55 pp., 2007.

Synolakis, C. E., Bernard, E. N., Titov, V. V., Kânoğlu, U., and Gonzalez, F. I.: Validation and verification of tsunami numerical models, in: Tsunami Science Four Years after the 2004 Indian Ocean Tsunami, Birkhäuser, Basel, 2197-2228, 2008.

Takagi, H., Mikami, T., Fujii, D., Esteban, M., and Kurobe, S.: Mangrove forest against dyke-break-induced tsunami on rapidly subsiding coasts, Nat. Hazards Earth Syst. Sci., 16, 1629-1638, https://doi.org/10.5194/nhess-16-1629-2016, 2016.

Tinti, S., Armigliato, A., Manucci, A., Pagnoni, G., Zaniboni, F., Yalçiner, A. C., and Altinok, Y.: The generating mechanisms of the August 17, 1999 Izmit bay (Turkey) tsunami: regional (tec- 
tonic) and local (mass instabilities) causes, Mar. Geol., 225, 311330, https://doi.org/10.1016/j.margeo.2005.09.010, 2006.

Tufekci, D., Suzen, M. L., Yalciner, A. C., and Zaytsev, A.: Revised MeTHuVA method for assessment of tsunami human vulnerability of Bakirkoy district, Istanbul, Nat. Hazards, 90, 943-974, https://doi.org/10.1007/s11069-017-3082-1, 2018.

Utkucu, M., Kanbur, Z., Alptekin, Ö., and Sünbül, F.: Seismic behaviour of the North Anatolian Fault beneath the Sea of Marmara (NW Turkey): implications for earthquake recurrence times and future seismic hazard, Nat. Hazards, 50, 45-71, https://doi.org/10.1007/s11069-008-9317-4, 2009.

Velioglu, D.: Advanced Two and Three Dimensional Tsunami Models: Benchmarking and Validation, Msc. Thesis, Middle East Technical University, Ankara, Turkey, 2009.

Wells, D. L. and Coppersmith, K. J.: New empirical relationships among magnitude, rupture length, rupture width, rupture area, and surface displacement, Bull. Seismol. Soc. Am., 84, 974$1002,1994$.

Wessel, P. and Smith, W. H.: New, improved version of Generic Mapping Tools released, Eos Trans. Am. Geophys. Union, 79, 579-579, https://doi.org/10.1029/98EO00426, 1998.

WGCEP - Working Group on California Earthquake Probabilities: Earthquake probabilities in the San Francisco Bay region: 20022031, US Geological Survey Open-File Report 03-214, US Geological Survey, Menlo Park, CA, 2003.

Wong, H. K., Lüdmann, T., Ulug, A., and Görür, N.: The Sea of Marmara: a plate boundary sea in an escape tectonic regime, Tectonophysics, 244, 231-250, https://doi.org/10.1016/00401951(94)00245-5, 1995.

Working Group on California Earthquake Probabilities: Earthquake probabilities in the San Francisco Bay Region: 2000 to 2030 a summary of findings, US Geol. Surv. Open-File Rept. 99-517, US Geological Survey, Menlo Park, CA, 1999.
Yalciner, A. C., Synolakis, C., Borrero, J., Altinok, Y., Watts, P., Imamura, F., Kuran, U., Ersoy, Ş. S., Kanoğlu, U., and Tinti, S.: Tsunami generation in Izmit Bay by the 1999 Izmit earthquake, Conferance on the 1999 Kocaeli Earthquake, Istanbul Technical University, Istanbul, Turkey, 217-221, 1999.

Yalciner, A. C., Altinok, Y., Synolakis, C. E., Borrero, J., Imamura, F., Ersoy, S., Kuran, U., Tinti, S., Eskijian, M., Freikman, J., Yuksel, Y., Alpar, B., Watts, P., Kanoglu, U., and Bardet, J.-P.: Tsunami waves in İzmit Bay, Earthq. Spect., 16, 55-62, 2000.

Yalçıner, A. C., Alpar, B., Altınok, Y., Özbay, İ., and Imamura, F.: Tsunamis in the Sea of Marmara: Historical documents for the past, models for the future, Mar. Geol., 190, 445-463, https://doi.org/10.1016/S0025-3227(02)00358-4, 2002.

Yalçıner, A., Annunziato, A., Papadopoulos, G., Dogan, G. G., Guler, H. G., Cakir, T. E., and Kanoglu, U.: The 20th July 2017 (22: 31 UTC) Bodrum-Kos Earthquake and Tsunami: Post Tsunami Field Survey Report, available at: http://users.metu.edu.tr/yalciner/july-21-2017-tsunami-report/ Report-Field-Survey-of-July-20-2017-Bodrum-Kos-Tsunami. pdf (last access: 11 December 2019), 2017.

Yaltırak, C.: Tectonic evolution of the Marmara Sea and its surroundings, Mar. Geol., 190, 493-529, https://doi.org/10.1016/S0025-3227(02)00360-2, 2002.

Youngs, R. R. and Coppersmith, K. J.: Implications of fault slip rates and earthquake recurrence models to probabilistic seismic hazard estimates, Bull. Seismol. Soc. Am., 75, 939-964, 1985.

Zolfaghari, M. R.: Development of a synthetically generated earthquake catalogue towards assessment of probabilistic seismic hazard for Tehran, Nat. Hazards, 76, 497-514, https://doi.org/10.1007/s11069-014-1500-1, 2015. 